\title{
Surfactant replacement therapy
}

\author{
Mitchell J Kresch, Winnie H Lin, Roger S Thrall
}

In 1959 Avery and Mead discovered that the lungs of infants who died of hyaline membrane disease (HMD) were deficient in surfactant. ${ }^{1}$ Surfactant reduces surface tension and stabilises alveoli at low lung volumes and may act as an "anti-stick" or lubricant allowing the alveolar walls to remain open..$^{2-4}$ HMD is characterised by progressive atelectasis and respiratory failure in premature infants and is a major cause of morbidity and mortality in the neonatal period. ${ }^{56}$ Numerous studies of the development of the pulmonary surfactant system have led to the clinical use of phospholipid composition of human amniotic fluid to predict lung maturity and to the use of antenatal hormones to accelerate lung maturation. Recently, this research has culminated in successful attempts to treat HMD in premature infants with surfactant replacement therapy (SRT).

We will begin this article with a brief review of the pulmonary surfactant system and the various types of surfactants used in replacement therapy. This will be followed by a review of the animal and clinical studies investigating SRT in various disease conditions.

\section{Biology of surfactant}

As shown in table 1, surfactant contains 85$90 \%$ lipids (of which $85 \%$ are phospholipids and $5 \%$ are neutral lipids) and $10-15 \%$ protein. ${ }^{278}$ The major phospholipid in surfactant is phosphatidylcholine of which approximately $70-75 \%$ is present as dipalmitoyl phosphatidylcholine (DPPC), the major surface active component in surfactant. The second most abundant phospholipid is phosphatidylglycerol (PG) which comprises 7-10\% of total surfactant. These lipids are important in the formation of the monolayer on the alveolar-air interface, and PG is important in the spreadability over a large surface area.

\begin{tabular}{|c|c|c|}
\hline $\begin{array}{l}\text { Connecticut Health } \\
\text { Center, Mail Code } \\
\text { 2203, Division of } \\
\text { Neonatology, } \\
\text { Farmington, } \\
\text { Connecticut 06030- }\end{array}$ & $\begin{array}{l}\text { veolar-air intertace, } \\
\text { spreadability over a }\end{array}$ & $\begin{array}{l}\text { and } P G \text { is important in th } \\
\text { large surface area. }\end{array}$ \\
\hline $\begin{array}{l}\text { M J Kresch } \\
\text { W H Lin } \\
\text { R S Thrall }\end{array}$ & $\begin{array}{l}\text { Lipid } \\
\text { Protein }\end{array}$ & $\begin{array}{l}\text { Percentage of total weight } \\
85-90 \\
10-15\end{array}$ \\
\hline $\begin{array}{l}\text { Correspondence to: } \\
\text { Dr M J Kresch }\end{array}$ & $\begin{array}{l}\text { Phospholipids } \\
\text { Neutral lipids } \\
\text { Glycolipids }\end{array}$ & $\begin{array}{l}\text { Percentage of lipids } \\
85-90 \\
5 \\
5-10\end{array}$ \\
\hline $\begin{array}{l}\text { Received } 7 \text { November } 1995 \\
\text { Returned to authors } \\
19 \text { April } 1996 \\
\text { Revised version received } \\
18 \text { June } 1996 \\
\text { Accepted for publication } \\
24 \text { June } 1996\end{array}$ & $\begin{array}{l}\text { Phosphatidylcholine } \\
\text { Dipalmitoyl } \\
\text { phosphatidylcholine } \\
\text { Phosphatidylglycerol } \\
\text { Phosphatidylethanolamine }\end{array}$ & $\begin{array}{l}\text { Percentage of total phospholipids } \\
70-80 \\
45-50 \\
7-10 \\
3-5\end{array}$ \\
\hline
\end{tabular}

There are four specific surfactant proteins which comprise $2-5 \%$ of the weight of surfactant. ${ }^{910}$ The most studied surfactant protein is SP-A which is expressed in alveolar type II epithelial cells and Clara cells in the lung. ${ }^{11-13}$ The gene for this protein is found on chromosome 10 and contains four exons that encode the primary translation product of $26-28 \mathrm{kD} .{ }^{910}$ Post translational glycosylation, hydroxylation of proline residues, and sialylation results in a glycoprotein doublet with apparent molecular weights of $28-30 \mathrm{kD}$ and 34-36 kD. 9-1114-18 The carboxy terminal globular glycosylated region contains two intramolecular disulphide bonds..$^{910}$ The N-terminal collagen-like regions from three monomers form a triple $\alpha$-helix that is important for the assembly of the protein. ${ }^{1920}$ The fully assembled molecule contains six of these oligomers with an apparent molecular weight of approximately $650 \mathrm{kD}^{21}{ }^{22} \mathrm{SP}-\mathrm{A}$ appears to be involved in the regulation of surfactant turnover, ${ }^{23-31}$ formation of tubular myelin, ${ }^{32}$ and the immune regulation within the lung. ${ }^{334}$

There are two hydrophobic surfactant specific proteins, SP-B and SP-C. ${ }^{9-11}{ }^{35-38}$ The gene for SP-B resides on chromosome 2 and contains 10 exons. ${ }^{910}$ The primary translation product is a $42 \mathrm{kD}$ protein which is cleaved to an active peptide of approximately $7-8 \mathrm{kD}$ under reducing conditions. ${ }^{39}$ The function of SP-B is not well understood, but it may be involved in the formation of tubular myelin. ${ }^{32}$ Recent studies have shown that SP-B is involved in the surface activity of surfactant and that this protein may increase the intermolecular and intramolecular order of the phospholipid bilayer, supporting the concept that SP-B resists surface tension by increasing the lateral stability of the phospholipid layer. ${ }^{40} \mathrm{~A}$ recent study confirmed that the 25 amino-terminal peptides of SP-B stabilised the phospholipid layer by increasing the collapse pressure of surfactant phospholipids which may prevent squeezing out of the phospholipids from the monolayers at the alveolar-air interface. ${ }^{41} \mathrm{~A}$ specific charge interaction between the cationic peptide and an anionic lipid such as PG may be responsible for this stabilisation.

The gene for SP-C resides on chromosome 8 and contains six exons resulting in a primary translation product of $21 \mathrm{kD} .^{9104243}$ This protein is cleaved into an active peptide of $4-5 \mathrm{kD} .{ }^{43}$ SP-C may be involved in the spreadability and surface activity of surfactant, but its 
Table 2 Types of surfactant used in clinical studies

\begin{tabular}{lll}
\hline Classification & Source & Surfactant protein content \\
\hline Natural surfactant & Human amniotic fluid & SP-A, SP-B, SP-C, SP-D \\
Modified natural surfactant & $\begin{array}{l}\text { Bovine lung extract (Survanta, Surfactant TA) } \\
\text { Bovine lung lavage extract (Infasurf) } \\
\text { Porcine lung extract (Curosurf) }\end{array}$ & SP-B, SP-C \\
Synthetic surfactant & $\begin{array}{l}\text { DPPC, PG, tyloxapol, hexadecanol (Exosurf) } \\
\text { DPPC:PG, artificial lung expanding compound (ALEC) }\end{array}$ & None \\
\hline
\end{tabular}

$\mathrm{DPPC}=$ dipalmitoyl phosphatidylcholine; $\mathrm{PG}=$ phosphatidylglycerol

exact function remains unknown. The most recently discovered surfactant specific protein, SP-D, is a glycoprotein with an apparent molecular weight of $43 \mathrm{kD}$ and contains an Nterminal collagenous domain and a carboxy terminal glycosylated domain similar to SPA. ${ }^{44-47}$ The function of SP-D is unknown at this time.

Pulmonary surfactant is synthesised in the alveolar type II epithelial cell and stored in the lamellar body. ${ }^{48-50}$ Secretion of surfactant into the airway occurs via exocytosis of the lamellar body by both constitutive and regulated mechanisms. ${ }^{24851}$ Numerous agents have been shown to stimulate the secretion of surfactant including $\beta$ adrenergic agonists, activators of protein kinase $C$, leukotrienes, and purinergic agonists. ${ }^{51-55}$ The major route of clearance of pulmonary surfactant within the lung is through reuptake by type II cells with minor contributions occurring through absorption into lymphatics and clearance by alveolar macrophages. ${ }^{5657}$ After being taken up by the type II cell, the phospholipids are either recycled for resecretion or degraded and reutilised in the synthesis of new phospholipids. ${ }^{58-62}$ These processes have recently been shown to be developmentally regulated in fetal lung. ${ }^{26}$

\section{Preparations used in surfactant replacement therapy}

There are three basic types of surfactant (natural, modified natural, and synthetic) that have been considered for SRT (table 2) ${ }^{6364}$ Natural surfactant from sheep and rabbits has been used in studies of the effects of SRT in preterm animals suffering from HMD. Several clinical trials in humans have used human natural surfactant which has been obtained from amniotic fluid from full term pregnancies. As would be expected, these natural surfactants contain all the phospholipids and neutral lipids as well as the surfactant proteins (SP-A, SP-B, SP-C, SP$D)$. A second type of surfactant used in SRT is the modified natural surfactant obtained from either bovine or porcine lung. These surfactants are obtained by organic solvent extraction of lung lavage or minced lung from bovine and porcine sources. The bovine preparations have been referred to as calf lung surfactant extract (CLSE or Infasurf), Surfactant TA, and the preparation which was approved by the FDA in 1991, Survanta. A porcine surfactant (Curosurf) has been used in Europe. In addition to containing the phospholipids of surfactant, these modified natural surfactants also contain the hydrophobic surfactant proteins SP-B and
SP-C, but they do not contain the hydrophilic proteins, SP-A and SP-D. Synthetic surfactants have been designed and one preparation contains surface active phospholipids as well as agents which improve spreadability and stability of the preparation. The first synthetic surfactant preparation that was approved for use by the FDA in 1990 was Exosurf which contains DPPC, PG, and the stabilisers tyloxapol and hexadecanol. Another synthetic surfactant that has been used in both animal research and clinical trials is called artificial lung expanding compound (ALEC) which is a mixture of DPPC and phosphatidylglycerol in a ratio of $7: 3$ by weight. ${ }^{65}$ The synthetic preparations do not contain the surfactant proteins. There are efforts currently underway, however, to develop engineered surfactants which contain synthetic phospholipids and recombinantly synthesised human surfactant proteins. The advantages of these surfactants are that they would not be from animal sources and they would contain the human surfactant proteins which may have important physiological roles in the function and metabolism of exogenously administered surfactant without the potential for antigenic stimulation of proteins derived from animal sources.

\section{Animal studies of surfactant replacement therapy}

Studies of SRT in animal models vary in their use of surfactant preparations, methods of administration, means of physiological assessment, and the species or the gestational age of the animals. This has created confusion in the field and makes comparison and interpretation of the studies very difficult. In general, studies which assess efficacy of surfactant preparations can be classified into three categories: (1) assessment of in vitro biophysical properties (surface activity, adsorption, and respreading abilities), (2) restoration of pulmonary function by surfactant preparations, and (3) in vivo physiological efficacy in premature animals. Detailed description and discussion of in vitro biophysical studies have been previously described and reviewed ${ }^{6466-78}$ and will not be discussed here.

\section{RESTORATION OF PULMONARY FUNCTION BY} SURFACTANT PREPARATIONS

Surfactant deficient model using excised lungs

The excised lavaged rat lung model, in which multiple lavages render the lung surfactantdeficient, provides a link between the in vitro biophysical data and the in vivo physiological 
activity of surfactants. ${ }^{79-82}$ Each lung acts as its own control and the efficacy of SRT is reflected by the short term improvement of quasistatic lung compliance measurements after lavage. Bermel and coworkers observed a progressive return to near normal quasistatic lung compliance in the surfactant-deficient model with increasing tracheal instillations of the modified natural surfactant, CLSE. ${ }^{83}$ Ikegami and coworkers studied the ability of various phospholipids to restore lung pressure-volume characteristics in excised lavaged rat lungs. ${ }^{84}$ Although various suspensions of DPPC and other phospholipids - for example, PG, phosphatidylinositol (PI), and phosphatidylserine (PS) - at a molar ratio of 9:1 had the ability to restore the pressure-volume characteristics toward normal, none was as effective as CLSE, suggesting that surfactant components other than the phospholipids were contributing to the overall functional activity of surfactant. ${ }^{84}$

Studies by McLean and coworkers used the excised lavaged rat lung model $l^{808185}$ and the in vivo lavaged guinea pig lung model ${ }^{80} 85$ to test the efficacy of several formulations of synthetic peptides and phospholipids. Various peptides including a synthetic peptide based on residues 81-102 of SP-A, an analogue of SP-A with increased amphipathic $\alpha$-helical potential, and the hydrophobic peptide gramicidin $\mathrm{D}$ were all ineffective as surfactant mixtures with DPPC in the excised lavaged rat lung model ${ }^{80} \mathrm{~A}$ later study tested three synthetic peptides, based on the putative amphipathic $\alpha$-helical region of SP-A, as SRT in the same model. ${ }^{81}$ The two peptides that corresponded to residues $81-102$ and 78-101 of natural SP-A were ineffective. An analogue peptide with substitution of leucine residues for aspartate ${ }^{84}$ and threonine ${ }^{90}$ of SP-A ${ }^{81-102}$ when mixed with DPPC, however, restored quasistatic lung compliance to $90 \%$ of the unlavaged value in the excised rat lung model. ${ }^{81}$ In addition, McLean et $a l^{80}$ demonstrated that a mixture of a lipid binding amphipathic $\alpha$-helical peptide, 18-As (based on the lipid binding sequences of the plasma apolipoproteins), and DPPC was effective in restoring lung function in the isolated rat lung model of surfactant deficiency. The 18-As peptide sequence is different from SP-A and, in fact, mixtures of SP-A like peptides with DPPC were ineffective in restoring lung function in this model. These studies showed that SPA, which is lacking in the* modified natural surfactant preparations, may not be a necessary component of replacement surfactant in restoring short term quasistatic lung compliance in the excised rat lung and in vivo guinea pig lavaged lung models.

Recently, Bruni and coworkers studied the effects of synthetic peptides of SP-B and SP$\mathrm{C}$ in combination with phospholipids and palmitic acid as replacement surfactants in the isolated rat lung model of surfactant deficiency. ${ }^{86}$ These synthetic peptides were modified to increase $\alpha$-helical structures and affinity for lipid layers (such as the oxidation of SP-B 1-78 by dimethylsulphoxide) and to enhance surface activity (such as the chemical acylation of SP-C 1-34). The synthetic peptides were shown to improve compliance by $10 \%$ in the surfactant-deficient isolated rat lung model. They concluded that synthetic surfactant peptides required biochemical modifications in order to assume secondary structures necessary for optimal function. Further studies may enable us to have a better understanding of the apoprotein-phospholipid interaction in the surfactant system, an important aspect for the success of SRT. Although these studies were successful in restoring compliance in these models, care must be taken in future evaluations using such synthetic peptides as they represent only fragments or parts of the entire complex and structural as well as conformational differences may exist which could complicate the interpretation of results. In conclusion, studies by McLean ${ }^{808185}$ and Bruni ${ }^{86}$ on the surfactant proteins indicated that SP-B and SP-C might be critical as components of replacement surfactant in the excised rat lung model whereas SP-A might not.

\section{Surfactant deficient model in vivo}

The in vivo lavaged adult guinea pig lung as an experimental model for SRT was first reported by Lachmann. ${ }^{87}$ In this model, alveolar surfactant phospholipids are removed by consecutive lung lavage and the short term survival of the animals is ensured by artificial ventilation. Biochemical, physiological, and histological findings after lavage were reported to mimic a pathological condition similar to the adult respiratory distress syndrome (ARDS) without causing severe damage to the alveolar structures. ${ }^{87}$ Berggren and coworkers instilled modified natural surfactant from minced porcine lungs in the guinea pig lavaged lung model. ${ }^{88}$ The surfactant-treated animals had significant improvement in gas exchange and alveolar air expansion, as shown by increased alveolar volume density on histological sections, when compared with a control group without treatment.

Adult rabbits subjected to lavage have also been used to study the effects of exogenous surfactant. ${ }^{89-92}$ Kobayashi and coworkers investigated the effects of modified natural surfactant obtained from porcine lung lavage fluid in "lung lavaged" rabbits. ${ }^{89}$ The survival rate, arterial blood gas tensions, and compliance of the group treated with both surfactant and positive end-expiratory pressure (PEEP) were significantly better than the groups which either received surfactant alone, PEEP alone, or no treatment at all. Oetomo and coworkers ${ }^{90}$ administered natural sheep surfactant to rabbits that were lavaged four times to remove $80 \%$ of the alveolar phospholipids. Results showed that treated animals were able to re-establish spontaneous breathing and maintain normal arterial blood gases following SRT while all the control animals without treatment died during the weaning-off regimen in which the PEEP level was lowered from 2.5 to $0 \mathrm{~cm} \mathrm{H}_{2} \mathrm{O}$. The same model has also been used for determining the effects of different forms of ventilation on hyaline membrane formation. ${ }^{9192}$ These studies compared conventional mechanical ventilation 
with a PEEP of $1-2 \mathrm{mmHg}$ (low) and PEEP equal to the inflection point pressure (high) in surfactant-deficient lavaged rabbits. Less lung damage was observed in the high PEEP group than those of the low PEEP group. ${ }^{9192}$ The authors concluded that high PEEP is advantageous in preventing alveolar collapse in neonatal RDS. These studies reaffirmed the usefulness of the lavaged rabbit lung model for testing the early effects of different surfactant preparations and ventilation patterns.

The benefit of the in vivo lavaged lung model over the in vitro excised lavaged lung model is the ability to detect a longer duration of effects of surfactant in living tissues. The disadvantage for both of these models, however, is the use of mature animals with fully developed lungs. These may not be relevant or applicable to neonatal HMD. Also, the capacity for surfactant regeneration in the mature lung may shorten the time course of recovery. Furthermore, the immature structure of the lung is a major factor in the pathogenesis of HMD. In addition, in order to have a meaningful determination of the efficacy of surfactant in these animal models, a standardised ventilation procedure is necessary because different ventilation manoeuvres may affect the outcome of the experiments. ${ }^{9192}$

IN VIVO PHYSIOLOGICAL EFFICACY IN PREMATURE ANIMALS

Perhaps the most relevant animal model for surfactant deficiency in HMD is the use of premature animals in vivo. ${ }^{93-118}$ Animals most commonly used are premature rabbits, ${ }^{94-101119-122}$ lambs, ${ }^{102-111118123-130}$ and baboons. ${ }^{112-117}$ It is more appropriate to extrapolate experimental findings from these preterm animals to the premature human infant.

\section{Rabbits}

Bronchiolar epithelial lesions that are similar to those in human HMD can be induced by artificial ventilation of 27 day gestation fetal rabbits (term is 31.5 days). Tracheal instillation of natural surfactant extracts from adult rabbits increase lung compliance and survival rate, and improves aeration of the lung parenchyma and resorption of fetal pulmonary fluid during spontaneous ventilation. ${ }^{96131}$

A study in premature 27-day rabbits showed that significantly more radiolabelled albumin administered via the airways was recovered from the airspaces in the surfactant-treated animals than controls; on the other hand, significantly less radiolabelled albumin administered intravenously had permeated into the alveolar compartment of the surfactanttreated animals than control animals. ${ }^{120}$ This indicated that SRT might improve lung function by reducing the leakage of surfactantinhibiting serum proteins into the alveolar spaces of premature rabbits.

Oetomo and coworkers ${ }^{90}$ studied the early effects of SRT on lung function and biochemical aspects using natural surfactant obtained from sheep lung lavage fluid. This surfactant improved survival when tested in vivo using immature rabbits and lambs with surfactant deficiency. ${ }^{90}$ Comparative studies of the effects of artificial surfactant and natural surfactant on premature rabbit lungs have generally shown an advantage of natural surfactant. ${ }^{111} 121122$ Morley and coworkers found that DPPC:PG in a 7:3 molar ratio and natural surfactant extract from rabbit lungs were both effective in improving lung compliance although hyaline membranes were present in all groups. ${ }^{121} \mathrm{~A}$ similar study compared DPPC: PG in various ratios with or without cholesterol or lyso-PC to natural surfactant extract from lavages of rabbit lungs. ${ }^{122}$ Although the synthetic mixtures showed promising biophysical effects in vitro, the same effect could not be confirmed in vivo as the effects of artificial surfactant were inferior to those of the natural surfactant in terms of the restoration of pressure-volume characteristics in preterm rabbits. ${ }^{122}$ Human surfactant, harvested from amniotic fluid, was given to premature rabbits and the treated animals showed improved chest excursion, decreased retractions of the rib cage during spontaneous breathing, and decreased death rate compared with control animals. ${ }^{100}$

Premature newborn rabbits were used to determine the relative efficacy of modified natural surfactant (Surfactant CK and Curosurf) versus apoprotein-based artificial surfactant. ${ }^{97132}$ The modified natural surfactants both contained the hydrophobic proteins SP-B and SPC. Results showed that the artificial preparation was beneficial in restoring lung compliance and alveolar volume density, but to a lesser degree than the same dose of the modified natural surfactants. It is possible that other components of surfactant may have essential properties that improve the physiological effects which might be required to make the artificial material comparable to modified natural surfactant.

Recently, the effects of natural surfactant and surfactant constituted with specific apoproteins in preterm rabbits were evaluated. ${ }^{101}$ Natural sheep surfactant was compared with synthetic surfactants containing the lipid components of surfactant to which SP-A, SP-B, or SP-C or combinations of the three apoproteins were added. Results showed that SP-A or SP-C, when added alone to surfactant lipids, failed to restore complete surfactant function in vivo. ${ }^{101}$ Surfactant lipids with SP-B alone, however, improved dynamic lung compliance in premature rabbits. The effects of surfactant lipids with SP-B alone were similar to the constituted surfactant containing all three surfactant proteins. This indicated that SP-B was mainly responsible for enhanced activity. However, none of the constituted surfactants were as effective as natural sheep surfactant. The authors expressed the difficulty in correlating in vitro biophysical measurements to functional activity of surfactant in vivo. SP-B and SP-C differ in their ability to alter the adsorption and spreading characteristics of lipid mixtures in vitro. Furthermore, the same study showed that sheep surfactant extracts without PEEP demonstrated effective responses, whereas the synthetic surfactants containing surfactant pro- 
teins without PEEP did not improve lung mechanics or protein leak responses. ${ }^{101}$

While the usefulness of the premature rabbit model in studies of SRT has been demonstrated, there are limitations to this model in that neither the effect of surfactant on gas exchange nor the duration of action was assessed. The period of ventilation possible in the preterm rabbit model is limited, allowing only the assessment of short term surfactant function.

\section{Lambs}

The need for other premature animal models that are conducive to long term ventilation prompted the use of lambs and baboons. ${ }^{102-118133}$ One advantage of premature lambs as an animal model for HMD is that births often occur as twins to allow experimental-control pairs for statistical analysis of data. ${ }^{109}$ In this model the relative improvement in blood oxygenation, lung mechanics, and survival can be assessed. ${ }^{110111}$ Treatment of premature lambs with natural sheep surfactant demonstrated improvement in pulmonary function (pressure-volume curves) and gas exchange (arterial $\mathrm{Po}_{2}, \mathrm{PCO}_{2}$, and $\mathrm{pH}$ ). The effect lasted for about eight hours in lambs treated at birth and only about three hours in lambs treated after the onset of respiratory failure. ${ }^{111118123128}$ CLSE also displayed excellent biophysical surface properties and had a pronounced effect on enhancing lung function in premature lambs in vivo. ${ }^{134}$

Jobe and coworkers investigated the kinetics of secretion of DPPC and the effects of natural sheep surfactant in lambs with or without pulmonary immaturity. ${ }^{108}$ Lambs prematurely delivered by caesarean section and term lambs were supported on ventilators and studied over a period of two days. Radiolabelled palmitic acid was injected systemically after birth to detect the appearance of endogenously synthesised and secreted DPPC in sequential airway samples of preterm lambs treated with sheep surfactant, in untreated lambs, and in term lambs. Instillation of natural sheep surfactant in premature lambs resulted in improvements in lung compliance and gas exchange. The kinetics of release of DPPC into lavage fluid was linear and similar in both preterm and term lambs.

The quantity of natural surfactant necessary to prevent HMD in premature lambs was studied by Ikegami and coworkers. ${ }^{124}$ Improvements in gas exchange and lung function in premature lambs receiving $19 \mathrm{mg} / \mathrm{kg}$ of natural sheep surfactant were similar to those receiving $53 \mathrm{mg} / \mathrm{kg}$ or more. The dose of surfactant $(53 \mathrm{mg} / \mathrm{kg})$ that resulted in good surface activity measurements in vitro was similar to other estimates of the amount of surfactant necessary to cover the alveolar surface. The authors concluded that the clinical response, rather than extrapolation from the dosage used in vitro, was the better way to evaluate the SRT. ${ }^{124}$ On the other hand, Walther and coworkers showed that multiple doses of natural sheep surfactant at $50 \mathrm{mg} / \mathrm{kg}$ were more effect- ive than a single initial dose administered after one hour of age to premature lambs with HMD, and the response to small, repetitive doses of surfactant was dependent on gestational age. ${ }^{125}$ The onset of therapeutic action of bovine lipid extract surfactant in premature lambs was shown to occur within five minutes of surfactant instillation. ${ }^{135}$ Major increases in functional residual capacity, vital capacity, and compliance took place within 5-20 minutes.

Ikegami and coworkers described the effects of natural sheep surfactant given to premature lambs on surface activity of lung lavage fluid. ${ }^{127}$ Alveolar washes from the treated animals and the natural surfactant all had similar phospholipid compositions. However, the alveolar washes from the treated animals contained about 40 times more protein per micromole phosphatidylcholine than the natural sheep surfactant. Correspondingly, the surface activities of the alveolar washes of the treated animals were considerably lower than the sheep surfactant. This indicated that the natural surfactant was inactivated by an inhibitor of surfactant function such as serum proteins and/ or other substances released from the vascular space. ${ }^{127}$ Natural versus modified natural surfactant without SP-A were compared in a study of SRT on proteinaceous alveolar oedema in premature lamb lungs. ${ }^{133}$ Intravascular radiolabelled albumin accumulation into premature lamb lungs was studied after SRT with either sheep surfactant or CLSE. The average net hourly albumin accumulation in the alveolar wash three hours after CLSE treatment was significantly higher than in those treated with sheep surfactant and not different from that in control lambs. However, by 24 hours the total protein in the alveolar washes of both surfactant-treated groups was similar to that measured in term newborn animals.

As in the premature rabbit model, different surfactant preparations have been tested for effectiveness in premature lambs. An artificial surfactant (a sonicated mixture of a 9:1 molar ratio of DPPC and PG) did not improve the lung compliance of unventilated premature lambs, whereas natural sheep surfactant resulted in improvement. ${ }^{105}$ It was concluded that the surface tension properties of artificial surfactant were reversibly inhibited by fetal lung fluid whereas the natural sheep surfactant was affected to a much lesser extent. ${ }^{105}$ CLSE was compared with an artificial surfactant composed of DPPC/PG in 7:3 molar ratio in terms of in vitro surface properties and in preterm lambs. ${ }^{109} \mathrm{CLSE}$ and DPPC/PG were able to lower surface tension to 1 dyne/cm under dynamic compression in vitro. However, the artificial surfactant did not improve lung compliance and arterial oxygenation. CLSE, on the other hand, improved the alveolar-arterial oxygen gradient, blood gas tensions, and lung compliance. A similar study compared natural sheep surfactant with an artificial surfactant composed of DPPC/PG in a 9:1 molar ratio in premature lambs. ${ }^{126}$ The artificial surfactant was not effective in restoring the pressurevolume characteristics of previously unventilated lamb lung, whereas the natural sur- 
factant was. ${ }^{126}$ The authors speculated that the poor response may be unique to the immature lung and suggested a new approach to the design of other artificial surfactants.

Cummings and coworkers reported that natural sheep surfactant, CLSE, and Survanta, but not Exosurf, improved oxygenation, lung mechanics, and survival in the premature lamb. ${ }^{111}$ This is in contrast to a previous study by Durand et $a l^{130}$ in which Exosurf was reported to be as effective as sheep surfactant in significantly improving the survival and pulmonary function in preterm lambs. Differences in methodology and prematurity of the lambs may explain the disparity in results. Cummings administered surfactant to 126-day lambs immediately after umbilical cord ligation, whereas Durand administered surfactant to 132-day lambs before cord ligation. ${ }^{111} 130$

A recent study of preterm lambs confirmed the better response in gas exchange and compliance to Survanta compared with synthetic, protein-free surfactant. ${ }^{136}$ After five hours of ventilation, large and small aggregate surfactant fractions were isolated from the bronchoalveolar lavage (BAL) fluid of the Survantatreated animals. The large aggregate fraction had the most surface activity and contained SP-A, SP-B, and SP-C. The small aggregates were ineffective as surfactants. BAL fluid from Survanta-treated lambs contained more SP-A than did BAL fluid from the lambs treated with the other surfactants. The surfactant recovered from preterm lambs increased compliance in surfactant-deficient immature rabbits. The large aggregate fractions which contain both the exogenous and endogenous surfactant pools in the BAL fluid from lambs treated with Survanta improved compliance in the preterm rabbits to a greater extent than did the original surfactants which contain only exogenous surfactant. Thus, exogenous surfactant may gain increased effectiveness from interaction with the endogenous pool of surfactant. The surfactant proteins appear to play an important role in this interaction in vivo.

\section{Baboons}

Premature baboons have been used as an alternative model of HMD and bronchopulmonary dysplasia (BPD). ${ }^{112-117}$ Two studies examined histological changes in the lungs of seven baboons delivered prematurely $(75 \%$ of full gestation) and one at term which were mechanically ventilated and exposed to high levels of inspired oxygen. ${ }^{112113}$ Six of the seven premature baboons developed pathological lesions of HMD and/or BPD. The histopathological features of the premature baboon model are similar to those of BPD in the human neonate. ${ }^{11213}$ Several studies have used the baboon model for the investigation of the prevention and treatment of HMD using surfactant. ${ }^{114-116}$

Surfactant TA $(100 \mathrm{mg} / \mathrm{kg})$, when administered to the premature baboon at $10 \mathrm{~min}$ utes of age, significantly improved the arterial/ alveolar oxygen ratio and pulmonary compliance, facilitated rapid weaning from assisted ventilation, and lung histological examination revealed no signs of early BPD. ${ }^{114}$ The saline control group revealed many features of early BPD such as dysplastic maturation, air trapping, or cellular atypia. ${ }^{114}$ Another study investigated the difference in clinical responses to early Surfactant TA treatment in the two HMD models (lambs in two groups at 125 and 132 days gestational age and baboons at 140 days gestational age). ${ }^{115}$ Term gestations for the lamb and baboon are 148 days and 187 days, respectively. The surfactant-treated baboons $(100 \mathrm{mg} / \mathrm{kg})$ were shown to have a sustained and significant improvement in arterial $\mathrm{Po}_{2}$ from the time of instillation to eight hours after treatment. The surfactant-treated lambs of 125 days gestation showed a good but transient response with an increase in the arterial/alveolar oxygen ratio and a decrease in mean airway pressure. No significant improvement in oxygenation was found among the treated and untreated 132-day lamb groups due to their advanced maturity and larger variance. The authors concluded that the differences in response to the same surfactant therapy among the lamb and baboon models were due to differences in species, lung maturation, and the differences in alveolar protein leakage. ${ }^{115}$

Investigators also studied the differences in early (10 minutes of age) and late (two hours of age) treatments using Surfactant TA in the baboon model of HMD. ${ }^{116}$ Both treated groups had significantly higher compliance and arterial/alveolar oxygen ratio and lower mean airway pressure and oxygen requirements than the untreated group. However, early surfactant treatment resulted in a greater improvement in lung mechanics than did late treatment.

\section{CORRELATION OF IN VITRO SURFACE PROPERTIES} AND PHYSIOLOGICAL RESPONSE

Recent evidence suggests that in vitro biophysical properties may not be important or may not predict in vivo response to surfactant. Correlation of in vitro surface properties and responses of preterm lambs to SRT was studied using four different surfactants: natural sheep surfactant, natural rabbit surfactant, natural human surfactant, and Surfactant TA. ${ }^{137}$ While fourfold less Surfactant TA was required to lower the minimum surface tension below 10 dyne/cm than for the other surfactants, Surfactant TA in preterm lambs was less effective than sheep surfactant in terms of improved gas exchange. The in vivo responses to rabbit surfactant were intermediate between the responses to sheep surfactant and to Surfactant TA. Human surfactant was the least effective surfactant in vivo in the study, possibly due to a problem of batch-to-batch variability. The study demonstrated that the range of clinical responses was not predictable based on the in vitro surface properties. ${ }^{137}$

Another investigation showed that three different surfactants effectively improved compliance and enhanced alveolar volume density in histological sections in preterm rabbits despite wide variations in surface properties. ${ }^{138}$ Surfactants tested were (1) natural surfactant 
extract from minced bovine lungs with rapid respreading and a relatively high minimal surface tension during surface compression; (2) bovine surfactant enriched with DPPC, tripalmitin, and palmitic acid with slow spreading and low minimal surface tension; and (3) bovine surfactant enriched with DPPC and dipalmitin with rapid spreading and low minimal surface tension. All three preparations were effective in vivo, illustrating that in vitro surface properties do not seem to influence the outcome of in vivo efficacy. ${ }^{138}$

In order to determine the specific surfactant properties necessary for improving gas exchange in premature animals, Tween 20 (a detergent of high surface tension and poor elasticity or compressibility as compared with natural surfactant) was tested in premature lambs. ${ }^{3}$ Tween 20 significantly improved gas exchange and lung compliance in preterm lambs. Another study showed that agents lacking the minimum surface tension and hysteresis of natural surfactant (such as the fluorocarbon FC-100 and Tween 20) were as effective as natural surfactant in improving lung expansion, gas exchange, and compliance in preterm lambs with respiratory failure. ${ }^{4}$ Taken together, these studies $^{34137138}$ indicate that surface activity may not be as important in improving gas exchange and lung compliance as previously thought. The anti-stick or lubricant properties of surfactant may play an important part.

\section{STRUCTURE-FUNCTION RELATIONSHIPS OF SURFACTANT COMPONENTS}

While the previously mentioned excised lavaged rat lung model and the in vivo lavaged lung model are adequate in generating initial physicochemical and physiological data of surfactant preparations, it is important to directly correlate in vitro surface activities with physiological activities in vivo. Tanaka and coworkers attempted to correlate surface activities, chemical composition, and physiological effects of Surfactant TA using the Wilhelmy balance, excised lavaged rat lung, and premature rabbits. ${ }^{139140}$ The investigators found that the content of DPPC in the Surfactant TA was the important determinant of minimum surface tension, the spreading rate, and pressure-volume characteristics in vitro and in vivo. ${ }^{139}$ Lung surfactant extract from minced bovine lung was supplemented with different kinds and amounts of fatty acids and triacylglycerols and their surface properties were tested in the excised lavaged rat lung model. Lung surfactants modified with palmitic acid-tripalmitoylglycerol and stearic acid-tristearoylglycerol gave better lung pressure-volume characteristics in the excised lavaged rat lung than those with oleic acid-triacylglycerols. The results showed that improved surface activity and physiological restoration of lung compliance were associated with surfactant that contained stearic acid, palmitic acid, and the hydrophobic surfactant proteins. Also, the fatty acids gave better surface activity than triacylglycerols. ${ }^{140}$

While it is important to correlate in vitro and in vivo activities of various surfactant pre- parations, it is also critical to determine the specific surfactant components that are responsible for the corresponding surfactant properties in vivo. Several recent studies have attempted to correlate surfactant phospholipid component structure with functional activities. Tanaka and coworkers prepared a series of 25 synthetic lung surfactant mixtures and tested the in vitro biophysical properties and physiological activities in premature rabbits. ${ }^{141} \mathrm{DPPC}$, the surfactant apoproteins, palmitic or stearic acid, and PG or phosphatidylserine all were shown to be important surfactant components for both in vitro and in vivo activities. Restoration of the compliance of excised rat lung with various phospholipids was investigated by Ikegami and coworkers. ${ }^{142}$ Treatment with 9:1 mixtures of DPPC with various other phospholipids - for example, DPPG, unsaturated phosphatidylinositol, unsaturated phosphatidylserine, PG, and lecithin - showed that DPPC:PG produced the most improvement in lung compliance but none of the phospholipid mixtures was as effective as natural surfactant.

Surfactant analogues were synthesised as probes for structure-activity studies as well as pharmacological tools to investigate phospholipid-surfactant protein interactions. Turcotte and coworkers synthesised and characterised a series of surfactant analogues structurally similar to the DPPC and other major glycerophospholipids in the surfactant system. ${ }^{66747578}$ These surfactant analogues were designed to be non-substrates for the phospholipases $\mathrm{A}_{1}$ (E.C. 3.1.1.32), $\mathrm{A}_{2}$ (E.C. 3.1.1.4), and D (E.C. 3.1.4.4). These analogues are more hydrophobic than DPPC. They demonstrated enhanced respreading facility in surface films on a Wilhelmy balance without any loss in dynamic surface activity (minimum surface tension of $<1 \mathrm{mN} / \mathrm{m}$ on Wilhelmy balance, oscillating bubble). Several analogues also had better adsorption than DPPC, although none approached the optimal behaviour of natural surfactant. The encouraging physical data suggested that these analogues may be useful probes for structuralactivity relationships relevant to pulmonary surfactant phospholipids. The first analogue to be tested was dimethyl(3-phosphonopropyl) ammonium, mono(2,3-bis-(hexadecyloxy)propyl)ester (DEPN-8), a diether phosphonate analogue of DPPC. ${ }^{667478}$ DEPN-8 had better surface activity than DPPC, including enhanced respreading facility in surface films on a Wilhelmy balance without any loss in dynamic surface tension lowering ability (minimums of $<1 \mathrm{mN} / \mathrm{m}$ on Wilhelmy balance, oscillating bubble). The analogue also had improved adsorption over DPPC, although it did not approach the optimal behaviour of natural surfactant. DEPN-8 partially restored lung compliance in surfactant-deficient excised rat lungs. ${ }^{66} \mathrm{DEPN}-8$, administered as a single agent in saline suspension ( 50 and $25 \mathrm{mg} / \mathrm{rat}$ lung), improved compliance in the excised rat lung significantly more than an equivalent amount of DPPC. The in vivo function of surfactants containing DEPN-8 was also investigated in preterm rabbits. ${ }^{143}$ DEPN-8 was 
Table 3 Efficacy of surfactant preparations in animal studies

\begin{tabular}{|c|c|c|c|c|c|c|}
\hline \multirow[t]{2}{*}{ Surfactants } & \multirow{2}{*}{$\begin{array}{l}\text { Biophysical } \\
\text { effects }\end{array}$} & \multicolumn{2}{|c|}{ Lavaged lung } & \multicolumn{3}{|c|}{ Premature animals } \\
\hline & & In vitro & In vivo & Rabbit & Lamb & Baboon \\
\hline $\begin{array}{l}\text { Natural } \\
\text { Sheep } \\
\text { Human }\end{array}$ & $\uparrow^{123137}$ & $\uparrow^{142}$ & & $\uparrow^{101120}$ & $\begin{array}{l}\uparrow^{102104} \\
\uparrow^{129}\end{array}$ & \\
\hline $\begin{array}{l}\text { Modified natural } \\
\text { CLSE } \\
\text { Survanta } \\
\text { Surfactant TA }\end{array}$ & $\begin{array}{l}\uparrow^{686973134} \\
\uparrow_{138}^{137139}\end{array}$ & $\begin{array}{l}\uparrow^{83} \\
\uparrow^{139}\end{array}$ & $\uparrow^{90}$ & $\begin{array}{l}\uparrow^{136138} \\
\uparrow^{139}\end{array}$ & $\begin{array}{l}\uparrow^{109-111134} \\
\uparrow_{111136}^{11113} \\
\uparrow^{115}\end{array}$ & $\uparrow^{114115}$ \\
\hline $\begin{array}{l}\text { Synthetics } \\
\text { Exosurf } \\
\text { DPPC/PG (7:3) } \\
\text { DPPC/PG (9:1) } \\
\alpha \text {-helical peptides } \\
\text { Surfactant analogues }\end{array}$ & $\begin{array}{l}\uparrow^{109} \\
\uparrow^{79} \\
\uparrow^{80} \\
\uparrow^{66747578}\end{array}$ & $\begin{array}{l}\uparrow^{84} \\
\uparrow^{79105} \\
\uparrow^{81} \\
\uparrow^{74}\end{array}$ & $\uparrow^{8085}$ & $\begin{array}{l}\downarrow^{136} \\
\uparrow^{105121} \\
\uparrow^{143}\end{array}$ & $\begin{array}{l}\uparrow^{130}, \downarrow^{111} \\
\downarrow^{109} 126134 \\
\downarrow^{105126}\end{array}$ & \\
\hline
\end{tabular}

$\uparrow$ Significant improvement versus control.

Insignificant improvement versus other preparations or control.

shown to be as effective as DPPC as lipid components of synthetic surfactants. Also, in a similar manner to DPPC, the analogue DEPN-8 interacted with SP-B and SP-C and improved in vivo function to levels comparable to natural sheep surfactant. Future studies of similar classes of surfactant analogues mixed with neutral lipids and/or proteins may further define the molecular components of natural surfactant that are critical for its specific surface active properties. These analogues can also be used as probes to study correlations between physicochemical and physiological activity. These probes may also further define the molecular components of natural surfactant that are critical for its functional activity. This may eventually guide the development of new surface-active molecules for potential improvement of synthetic surfactant replacement mixtures.

EFFICACY OF SRT IN ANIMAL MODELS OF ARDS Bovine lipid extract surfactant was used therapeutically in various animal models of ARDS. ${ }^{144-146}$ A mouse model for influenza A virus and a rat model for Sendai virus were used to induce viral pneumonia with acute disease closely resembling ARDS. ${ }^{144}$ The reduced arterial oxygenation and pulmonary compliance caused by the loss of surfactant function during viral pneumonia were almost completely restored by SRT using bovine lipid extract surfactant. Bovine surfactant was also shown to improve pulmonary function and gas exchange in a rat model for Pneumocystis carini pneumonia. ${ }^{145146}$ These findings indicated the usefulness of SRT for the treatment of respiratory failure due to severe viral pneumonia.

Engstrom and coworkers reported that CLSE increased 72 hour survival of rabbits that were exposed to $100 \%$ oxygen by attenuating the increase in lung protein permeability usually found in hyperoxia-induced lung injury. ${ }^{147}$ Curosurf, however, did not improve the blood gases, nor the compliance at a late stage (85-88 hours) of hyperoxia-exposed guinea pigs, possibly due to the presence of inhibitory components in the lung oedema fluid. ${ }^{148}$ These results indicated that surfactant might be more effective at an earlier stage of the disease. There was a concentration- dependent inhibition of surfactant function by the lung oedema fluid from animals exposed to hyperoxia. ${ }^{149}$ Survanta reduced the recoil of both excised lung and lungs in vivo acutely injured by acid aspiration, but did not improve gas exchange. ${ }^{150}$ The authors related their results to those of Jacobs et al with Tween-20 mentioned previously, further demonstrating that the properties of surfactant thought to be responsible for improving lung compliance were quite different from those contributing to improved gas exchange. Sheep surfactant was shown to improve the arterial blood gas values and lung compliances in acute lung injury (as characterised by pulmonary oedema, decreased lung compliance, and atelectasis) induced by bilateral cervical vagotomy in adult rabbits. ${ }^{151}$ Again the exogenous surfactant was thought to overcome in part the detrimental effects of inhibitory plasma proteins in pulmonary oedema. In addition, bovine surfactant significantly improved blood gases and lung mechanics in guinea pigs with acute lung injury induced by intravenous injection of an anti-lung serum. ${ }^{152}$ Thus, the effects of SRT in various ARDS models was beneficial but dependent on the type of animal model, the degree of lung injury at the time of treatment, and the initiation of treatment.

Table 3 summarises the efficacy of various surfactant preparations as reported by the specific studies. The results of these studies can be classified into two categories: (1) significant improvement with treatment, or (2) insignificant improvement compared with other preparations of surfactant or control.

\section{Clinical studies of neonatal HMD}

Initial studies using tracheal instillation or nebulised administration of a synthetic mixture of DPPC and PG did not show any effect on the clinical course or gas exchange in infants with HMD. ${ }^{153-155}$ These trials, using an aqueous mixture of these phospholipids sometimes referred to as artificial lung expanding compound (ALEC), did not include agents that would improve the adsorption and spreadability of these preparations over the alveolar surface. The first successful attempt to improve the condition of infants suffering from HMD was by Fujiwara and his associates using modified natural bovine surfactant extract in an uncontrolled pilot study of 10 infants suffering from $\mathrm{HMD}^{156}$ in whom an improvement in oxygenation and a decreased need for mechanical ventilation was reported. Since then numerous randomised controlled clinical trials have been performed documenting the efficacy and safety of exogenous SRT in neonates suffering from HMD. Two strategies have been used in these studies: a rescue strategy in which infants with documented HMD are then treated with SRT, and a prophylactic approach in which all eligible infants at risk for developing HMD are treated either at the time of birth or as soon as possible thereafter.

\section{RESCUE STUDIES}

There have been many studies showing that SRT of infants suffering from HMD results in 
significant improvements in gas exchange (as measured by oxygenation index, blood gas analysis) and ventilator settings, such as mean airway pressure, $\mathrm{FIO}_{2}$, and peak inspiratory pressure. ${ }^{157-172}$ Most studies have also shown a reduction in the incidence of pulmonary air leak - that is, pneumothorax, pulmonary interstitial emphysema, pneumomediastinum and pneumopericardium - as well as improved survival of infants treated with SRT. Unfortunately, none of the studies have shown a consistent effect on the incidence of chronic lung disease (bronchopulmonary dysplasia), duration of hospital stay, duration of mechanical ventilation, or other neonatal problems including patent ductus arteriosus (PDA), intraventricular haemorrhage (IVH), and necrotising enterocolitis. One prospective randomised controlled multicentre trial did document an increased incidence of $\mathrm{IVH}^{162}$ and another study showed an increase in the incidence of $\mathrm{PDA}^{157}$ in infants treated with surfactant, but neither of these findings have been confirmed by other studies.

\section{Modified natural surfactant}

In a double blind, randomised, controlled trial Surfactant TA treatment of preterm infants suffering from HMD with birth weights of $750-1750 \mathrm{~g}$ improved oxygenation and ventilation, reduced the incidence of pneumothorax and pulmonary interstitial emphysema, but was associated with an increased incidence of PDA. ${ }^{157}$ Survival without bronchopulmonary dysplasia (BPD) was associated with SRT. Gitlin and colleagues found that treatment with Surfactant TA of infants of birth weights 1000-1500 g with HMD improved oxygenation and ventilation within four hours of treatment. ${ }^{158}$ Treatment was associated with fewer pneumothoraces and there were no adverse effects. There were no effects on the occurrence of PDA, IVH, BPD, or mortality; $11 \%$ of infants did not respond to treatment. Fujiwara and coworkers reported that treatment with single doses of Surfactant TA of infants with HMD weighing $750-1750 \mathrm{~g}$ enrolled in a multicentre randomised controlled trial reduced the severity of $H M D$, reduced the incidence of pneumothorax, pulmonary interstitial emphysema, and $\mathrm{IVH}$, and improved survival without BPD. ${ }^{159}$ There were no effects of SRT on the incidences of PDA, pulmonary haemorrhage, or mortality.

A randomised controlled trial comparing single versus multiple doses of CLSE for infants 30-36 weeks gestation with HMD showed that surfactant improved oxygenation rapidly within 10 minutes, and the effect lasted up to 48 hours in both single and multiple dose groups. ${ }^{160}$ Approximately $70-80 \%$ of infants had transient responses and met criteria for retreatment. ${ }^{160}$ There were no differences in the short term complications or long term outcome.

Randomised controlled trials of Survanta treatment of $\mathrm{HMD}$ in infants weighing $750-1750 \mathrm{~g}$ revealed that surfactant improved oxygenation, reduced mean airway pressure needed for mechanical ventilation, and reduced the incidence of pulmonary air leaks. ${ }^{161} 162$ There were no effects on the incidences of PDA, BPD or necrotising enterocolitis, but one study showed an alarming increase in the incidence of IVH associated with SRT. ${ }^{162}$ Multiple doses of Survanta therapy of HMD in infants weighing $600-1750 \mathrm{~g}$ resulted in improvements in oxygenation and ventilation, reduction of pulmonary air leaks and mortality, and improved survival without BPD. ${ }^{163}$ There were no effects on the incidences of PDA, necrotising enterocolitis, IVH, or pulmonary haemorrhage.

Treatment of infants with HMD weighing 700-2000 g using porcine surfactant extract (Curosurf) resulted in improved oxygenation and ventilation, reduced pulmonary air leak, reduced mortality, and decreased incidence of BPD. ${ }^{164-166}$ Multiple doses of Curosurf were more effective than single doses in the reduction of the incidences of pneumothorax and neonatal mortality. ${ }^{167}$

Natural human surfactant treatment of HMD in infants of 24-32 weeks gestation improved oxygenation and ventilation, reduced the incidence of pulmonary air leak, and improved survival without BPD. ${ }^{168169}$ The improvement in survival was associated with increased birth weight, earlier age at treatment, and female gender. ${ }^{169}$

Approximately $21 \%$ of infants treated with surfactant will have a transient response and between $10 \%$ and $30 \%$ of infants will have no response to SRT. ${ }^{160} 173$ Several factors have been shown to influence the response to SRT in babies with HMD. The response to treatment is attenuated by several factors including asphyxia, male sex, and severity of the disease at the time of treatment. ${ }^{173174}$ In addition, response to treatment may be improved by early treatment within three hours of birth compared with later treatment at 15 hours of age. ${ }^{175}$ Thus, it is possible that such differences in factors affecting the response to treatment may account for the lack of a consistent improvement in long term outcome measures such as survival and incidence of BPD.

Administration of surfactant in two fractional doses through a suction valve that did not require removal of the infant from the ventilator was as effective as administration using either two or four fractional doses given after removal from the ventilator. ${ }^{176}$ Thus, SRT can be given to an infant without interrupting mechanical ventilation which results in fewer episodes of reflux of surfactant into the endotracheal tube and fewer episodes of oxyhaemoglobin desaturation during administration. ${ }^{176}$

Several studies have shown that exogenous SRT is not associated with enhanced lung inflammation although there is an increase in the number of alveolar macrophages recovered from bronchoalveolar lavage fluid in the third to seventh days of life. ${ }^{177178}$ Since the modified natural surfactant preparations contain the hydrophobic surfactant proteins, there is a potential for antigenic stimulation of infants treated with these preparations. Infants suffering from HMD have more permeable pulmonary capillaries which may lead to ab- 
sorption of surfactant proteins into their bloodstream, thus exposing them to these antigens. Surfactant therapy was associated with a decrease in the transient rise of $\operatorname{IgM}$ antibody to surfactant proteins, SP-A, SP-B and SP-C, ${ }^{179}$ suggesting that such therapy may reduce the leak of surfactant proteins into the vascular space by reducing lung damage. Another study showed that none of the infants treated with modified natural surfactants developed antibodies to SP-B or C after they had recovered. ${ }^{180}$

Compared with controls, there is no difference in long term developmental outcome of infants treated with surfactant as measured by the Bayley mental or motor scale at 12 and 24 months of age. ${ }^{181}$ SRT has been shown to be cost effective by improving survival without increasing overall hospital costs. Total hospital charges to produce a surviving infant were over US $\$ 18000$ less in infants treated with SRT in one study. ${ }^{182}$

A Medline search of the English literature of all randomised controlled trials of surfactant therapy used in infants was performed to conduct a meta-analysis. Studies were grouped into five categories: rescue therapy with modified natural surfactant, rescue therapy with synthetic surfactant, prophylaxis with modified natural surfactant, prophylaxis with synthetic surfactant, and rescue therapy versus prophylaxis with modified natural surfactant. We determined the relative risk ratio for each study (proportion of treated infants with the outcome variable/proportion of control infants with the outcome variable), and mean $\pm 95 \%$ confidence intervals (CI) were calculated for each risk ratio. Risk ratios in which the $95 \%$ CI do not include 1 indicate a significant change in the risk for that variable, a relative risk ratio of $<1$ indicates a reduced risk for that variable, and a risk ratio of $>1$ signifies an increased risk for that variable.

A meta-analysis of modified natural surfactant extracts used in rescue therapy of infants with HMD weighing $700-2000 \mathrm{~g}$ is shown in table 4 and fig 1A. There was a significant decrease in the incidence of pneumothorax associated with SRT as well as a significant decrease in mortality. Significantly more infants survived without chronic lung disease if they had been treated with SRT using the modified natural surfactants. There was no effective change in the incidence of BPD.

Two studies of SRT in full term newborn infants have been reported. In a prospective uncontrolled trial using calf lung surfactant extract in full term infants suffering from a variety of causes of respiratory failure surfactant treatment was associated with a significant im-

Table 4 Meta-analysis of rescue studies of surfactant therapy

\begin{tabular}{lllllll}
\hline & \multicolumn{2}{l}{ Modified natural surfactant } & & \multicolumn{2}{l}{ Synthetic surfactant } \\
\cline { 2 - 3 } & Control & Treated & & & Control & Treated \\
\hline Pneumothorax & $41.9(5)$ & $16.4(3.8)$ & & $34.7(6.1)$ & $28.9(7.8)$ \\
BPD & $29.4(3.8)$ & $25(4.6)$ & & $35.5(12.1)$ & $28(8.1)$ \\
Mortality & $31(4)$ & $20.5(2.3)$ & & $30.6(7.8)$ & $23.5(7.6)$ \\
Survival without BPD & $42.2(5.7)$ & $60.8(5.6)$ & & $44.6(9.2)$ & $56.5(9.7)$ \\
\hline
\end{tabular}

$\mathrm{BPD}=$ bronchopulmonary dysplasia.
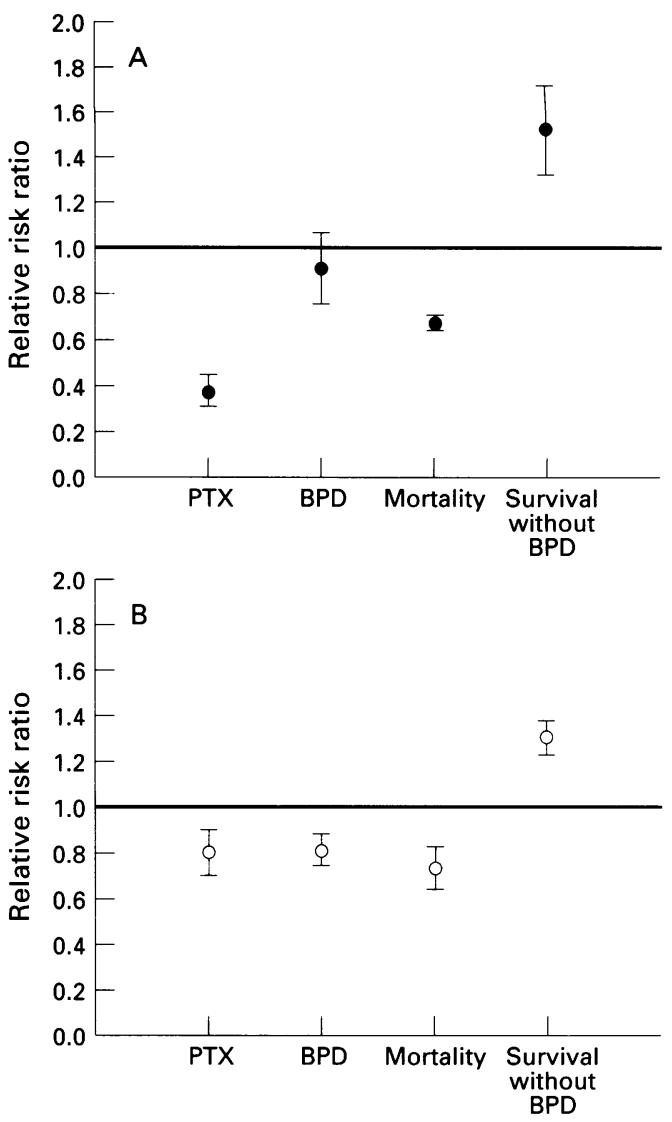

Figure 1 Meta-analysis of rescue trials using $(A)$ modified natural surfactant and (B) synthetic surfactant. Data represent the mean $\pm 95 \%$ confidence intervals for relative risk ratios for pneumothorax (PTX), bronchopulmonary dysplasia (BPD), mortality, and survival without BPD. Confidence intervals which do not include the risk ratio of 1 indicate significant reductions $(<1)$ or increases (>1) in the chances for a particular outcome variable.

provement in oxygenation. ${ }^{183}$ This study indicated that surfactant supplementation may be of benefit in newborn infants with respiratory failure due to either pneumonia or meconium aspiration syndrome. Unfortunately, no prospective randomised controlled trial of surfactant in this population has been performed. In an uncontrolled retrospective series SRT was associated with an improvement in oxygenation in full term infants with respiratory failure due to RDS. ${ }^{184}$ There was no significant response in terms of oxygenation of infants with meconium aspiration syndrome treated with surfactant. At this time it appears that a randomised controlled trial of SRT in full term infants is warranted.

\section{Synthetic surfactant}

Studies with Exosurf in the rescue of infants suffering from HMD have shown that $35-40 \%$ of infants treated show a transient response or no response at all. ${ }^{170}$ Exosurf treatment of HMD in infants weighing $>650 \mathrm{~g}$ resulted in improved oxygenation and ventilation, ${ }^{170}$ but $36 \%$ of infants had a transient response to therapy. Exosurf therapy of infants with HMD weighing $>1250 \mathrm{~g}$ reduced the incidences of pneumothorax, IVH, and PDA, improved oxygenation and ventilation, improved survival, 
and reduced the incidence of BPD. ${ }^{171}$ Infants weighing 700-1350 g treated with Exosurf had improved oxygenation and ventilation, reduced pulmonary air leaks, and improved survival. ${ }^{172}$ The incidence of BPD was not affected although survival without BPD was improved. ${ }^{172}$ Thus, most studies of synthetic surfactant used for rescue therapy have shown improvement in oxygenation and decreased need for mechanical ventilation. ${ }^{170-172} 185186$ This improvement in oxygenation occurs about six hours later than that produced with modified natural surfactant. ${ }^{187}$ Although these acute effects on oxygenation and ventilation appear to favour modified natural surfactants, the incidence of chronic lung disease and survival without chronic lung disease are not different between these preparations.

There have been several studies comparing early and late rescue SRT. The OSIRIS Collaborative Group in Europe conducted the largest multicentre randomised trial ever performed in neonatal medicine. ${ }^{188}$ They compared administration of Exosurf at a mean of 118 minutes after birth with administration at approximately three hours after birth. The infants receiving earlier treatment had significantly fewer pneumothoraces and a significantly greater number survived without chronic lung disease. ${ }^{188}$ Interestingly, the study showed that it was unlikely that the third and fourth doses of Exosurf had any important clinical benefit when compared with the effects of the first two doses.

Treatment of infants with HMD using synthetic surfactant results in a decrease in pulmonary artery pressure and an increase in blood flow through the ductus arteriosus. ${ }^{189190}$ Synthetic SRT used in the treatment of infants with HMD has been shown to decrease airway resistance and decrease the work of breathing in these infants. ${ }^{191}$ Long term follow up has shown that, compared with controls who did not receive Exosurf, infants treated with synthetic surfactant have decreased airway resistance and decreased work of breathing as early as three months of age, and this effect persists to at least 12 months of life. ${ }^{191}$ In a non-randomised trial, Exosurf therapy was associated with a $35 \%$ increase in cerebral blood flow. ${ }^{192}$ This transient increase in blood flow velocity to the brain may place these infants at risk for intraventricular haemorrhage which might explain the lack of a consistent reduction in the incidence or severity of intracranial haemorrhages in infants treated with SRT.

One study showed that Exosurf resulted in enhanced mucociliary clearance of respiratory secretions. ${ }^{193}$ This was associated with less viscous mucus obtained from infants treated with synthetic surfactant. ${ }^{193}$ Thus, it is possible that synthetic surfactant may improve oxygenation and ventilation in infants in part by improving the quality of mucus in the respiratory tree, making it less viscous and better transported and cleared.

A meta-analysis of the studies involving synthetic surfactant in the rescue of infants suffering from HMD is shown in table 4 and fig $1 \mathrm{~B}$.
There is a consistent decrease in the incidence of air leaks and a decrease in both mortality and the incidence of BPD in infants treated with synthetic surfactant. The reduction in the relative risk of pneumothorax (relative risk 0.8) is not as prominent as that associated with treatment using modified natural surfactant (relative risk 0.4). Similar to modified natural surfactant, synthetic surfactant treatment enhances survival of infants without BPD.

Which preparation of surfactant is more efficacious? A recent randomised controlled study compared the efficacy of modified natural surfactant (Survanta) with synthetic surfactant (Exosurf). ${ }^{194}$ Infants receiving modified natural surfactant had a more rapid improvement in oxygenation and ventilation, but there were no differences in long term outcome variables such as the development of BPD, mortality, and survival without BPD. The potential benefit of more rapid improvements in gas exchange with concomitant weaning of ventilator support did not result in improved long term outcome. This makes recommendations of one preparation over another difficult. The choice of which preparation to use is a matter of individual preference until further comparative studies are published.

\section{PROPHYLAXIS STUDIES \\ Modified natural surfactant}

There have been several studies using modified natural surfactant for the prevention of HMD in infants of $<30$ weeks gestation. Administration of CLSE to infants of $<30$ weeks gestation prior to the first breath significantly decreases the incidence of RDS from $64 \%$ (control group) to $36 \%$ (treated group) and results in a significant improvement in ventilatory index and oxygenation ${ }^{195}$ associated with a decrease in the need for supplemental oxygen and mean airway pressure used to ventilate the infants. ${ }^{196}$ In addition, there are significantly fewer air leaks (pneumothorax and pulmonary interstitial emphysema) and an increase in survival in the infants treated with surfactant. Prophylaxis with CLSE in infants of 25-29 weeks gestational age also results in a decrease in the severity of disease. ${ }^{197}$ Prophylactic treatment of infants of 24-30 weeks gestational age with Survanta is associated with decreased incidence of RDS, less severe radiographic changes on the chest radiograph, decreased incidence of pneumothorax, and improved survival without chronic lung disease. ${ }^{198}$ Prophylaxis with Survanta reduced the incidence of HMD, improved oxygenation and ventilation, reduced the risk of pulmonary air leaks, improved survival, and improved survival without BPD in infants of 23-29 weeks gestation (weighing 600-1250 g). ${ }^{199}$ These effects were most pronounced in the infants weighing $<1000$ g. A multicentre randomised controlled trial of bovine surfactant in Europe also documented an improvement in survival without chronic lung disease (from $40 \%$ to $76 \%$ ) in infants of 25-30 weeks gestation receiving prophylaxis. ${ }^{200}$ 
Table 5 Meta-analysis of prophylaxis studies of surfactant therapy with modified natural surfactant

\begin{tabular}{lll}
\hline & Control & Treated \\
\hline Incidence of HMD & $58.1(3)$ & $28.2(3.7)$ \\
Pneumothorax & $24.1(5.8)$ & $12.2(5.4)$ \\
BPD & $45.5(7.6)$ & $33.6(7.3)$ \\
Survival & $76.5(5.4)$ & $91(2.3)$ \\
Survival without BPD & $35.2(7.6)$ & $64.2(5.5)$ \\
\hline
\end{tabular}

$\mathrm{HMD}=$ hyaline membrane disease $\mathrm{BPD}=$ bronchopulmonary dysplasia.

Natural human surfactant for the prevention of HMD significantly improved gas exchange, survival, and survival of infants without chronic lung disease. ${ }^{201}$ The surviving surfactant treated infants spent almost two months less time in a neonatal intensive care unit than control infants. $^{201}$

Overall, most of the studies using natural or modified natural surfactant to prevent HMD have shown a reduction in the incidence of HMD, improved survival, and decreased incidence of BPD in infants of $<26$ weeks gestation or $<1000 \mathrm{~g}$ birth weight. Prophylactic therapy is associated with improved gas exchange as well as a decrease in air leaks. The variations in efficacy between studies are probably due to differences in strategy in ventilation as well as the differences in preparations and time of administration. A recent study has shown that a ventilator strategy using higher mean airway pressures and lower supplemental oxygen concentrations may be associated with better efficacy of prophylactic human SRT. ${ }^{202}$

A meta-analysis of the prophylactic studies using modified natural surfactant is shown in table 5 and fig 2A. Overall, the incidence of RDS has been significantly decreased by $50 \%$. There is a decrease in the risk for pneumothorax and BPD and an increase in survival. The number of survivors without BPD is also significantly improved with prophylactic therapy. About $30 \%$ of infants treated prophylactically with surfactant preparations, however, develop HMD.

\section{Synthetic surfactant}

Exosurf. Prophylactic therapy with Exosurf does not reduce the incidence of RDS. ${ }^{203204}$ Synthetic surfactant treatment within one hour of birth of infants weighing 700-1350 g improves gas exchange, reduces ventilator settings with lower mean airway pressures, reduces the incidence of air leak, and improves survival without BPD compared with controls. ${ }^{170203204}$ There are no significant effects on the occurrence of pneumothorax, intracranial haemorrhage, chronic lung disease, or mortality. Apgar scores at both one and five minutes were lower in the treatment group in one study. ${ }^{170}$

As shown in table 6 and fig 2B, meta-analysis reveals that prophylactic synthetic surfactant does not prevent HMD. The incidence of HMD in both treated and control infants remains about $50 \%$, and there is no reduction in the relative risk of $\mathrm{HMD}$ (fig $2 \mathrm{~B}$ ). The relative risk of pneumothorax is reduced by $40 \%$ using synthetic surfactant as prophylaxis, and there is an increase in survival as well as survival
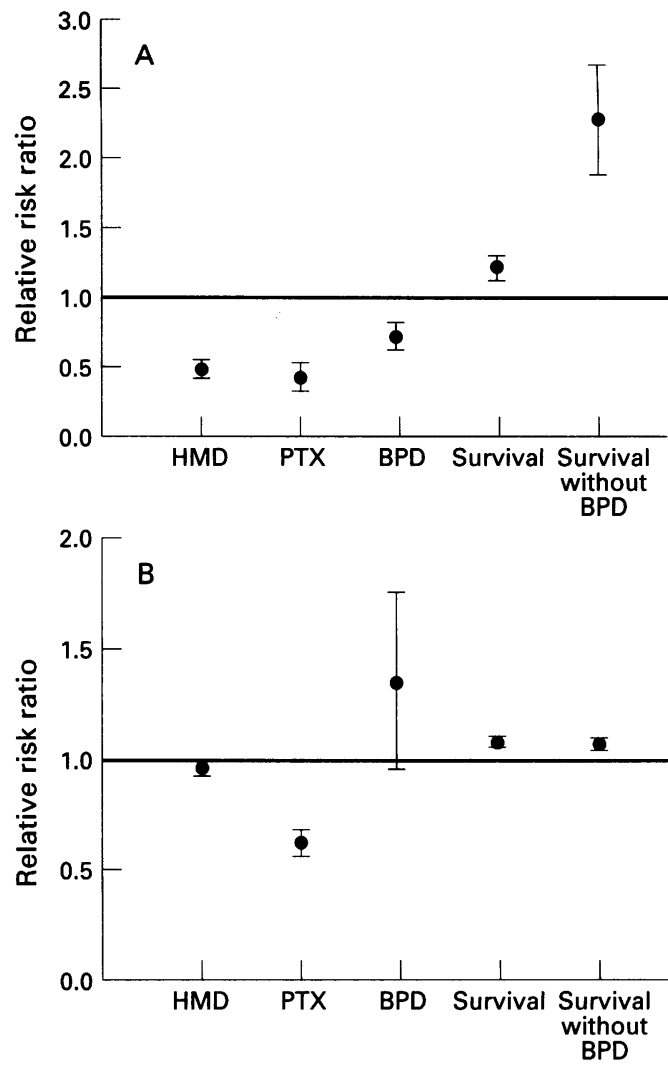

Figure 2 Meta-analysis of prophylaxis trials using $(A)$ modified natural surfactant and (B) synthetic surfactant. Data represent the mean $\pm 95 \%$ confidence intervals for relative risk ratios for the incidence of hyaline membrane disease (HMD), pneumothorax (PTX), bronchopulmonary dysplasia (BPD), survival, and survival without BPD. Confidence intervals which do not include the risk ratio of 1 indicate significant reductions $(<1)$ or increases (>1) in the chances for a particular outcome variable.

without chronic lung disease (fig 2B). Synthetic surfactant used prophylactically has no effect on the development of BPD (table 6, fig 2B). As shown in fig 2 , the efficacy of modified natural surfactant appears greater than synthetic surfactant in each of the outcomes analysed. Overall, there appears to be a significant decrease in the Apgar score at one minute, with one study showing a decrease in the Apgar score at both one and five minutes which raises the question of whether this could lead to significant adverse effects in the long term. Since SRT has been associated with cerebroelectrical depression ${ }^{205}$ as well as significant changes in cerebral blood flow, ${ }^{192}$ this could predispose to adverse outcomes both in the short term with intraventricular haemorrhage and in long term neurodevelopmental sequelae. These potential adverse effects may explain why there is not a decrease in intraventricular

Table 6 Meta-analysis of prophylaxis studies of surfactant therapy with synthetic surfactant

\begin{tabular}{lll}
\hline & Control & Treated \\
\hline Incidence of HMD & $50.3(4.7)$ & $48.3(6.6)$ \\
Pneumothorax & $32.1(10.1)$ & $19.5(6.1)$ \\
BPD & $15.1(5.3)$ & $16.3(2.7)$ \\
Survival & $82.1(3.5)$ & $89(2.4)$ \\
Survival without BPD & $69.1(2.7)$ & $74.2(2.4)$ \\
\hline
\end{tabular}

$\mathrm{HMD}=$ hyaline membrane disease; $\mathrm{BPD}=$ bronchopulmonary dysplasia. 
haemorrhage associated with the decrease in the incidence and severity of HMD following treatment with SRT. This is certainly an area for future study.

Artificial lung expanding compound (ALEC). Two randomised controlled clinical trials of ALEC have been conducted. In a study in infants of 23-34 weeks gestation ${ }^{206}$ only infants of less than 30 weeks gestation treated with ALEC had improved gas exchange (lower oxygen requirements), improved compliance (lower average peak inspiratory pressures), and reduced mortality. These infants also had fewer intraventricular haemorrhages and fewer infants in the treated group required oxygen for more than 28 days. There was no effect on the incidence of pneumothorax. Another multicentre trial of ALEC given at birth to infants of 25-29 weeks gestation, which included the data from infants of 25-29 weeks gestation in the first study, showed improved survival in the treated infants. ${ }^{207}$ Thirty percent of the control infants died during their stay in the neonatal unit compared with $19 \%$ of the treated infants. There was no effect on pulmonary air leaks (pneumothorax and pulmonary interstitial emphysema), and the effects on IVH and chronic lung disease were not seen in this larger trial. Of the infants treated with ALEC, $64 \%$ developed HMD compared with $75 \%$ of the control infants, and there was a trend towards less severe HMD in the treated infants compared with the controls. Thus, ALEC was associated with improved survival, a slight reduction in the incidence of HMD, and a decrease in the severity of HMD in infants of less than 30 weeks gestation. The effects were not evident for the first six hours and there was no effect on the incidence of pulmonary air leaks. The slower onset of action of ALEC compared with the modified natural surfactants may explain the lack of effect on pulmonary air leaks.

\section{STUDIES COMPARING PROPHYLAXIS AND RESCUE} THERAPY

There have been several randomised controlled trials comparing SRT given prophylactically at birth with rescue administration in very low birth weight infants suffering from HMD. Natural human surfactant decreased the incidence of pulmonary interstitial emphysema and improved gas exchange in infants treated with either prophylactic or rescue therapy compared with infants receiving placebo. ${ }^{208}$ Prophylactic therapy with human surfactant was, however, associated with an increased incidence of retinopathy of prematurity when compared with rescue therapy. ${ }^{208}$ At follow up, significantly more infants in the prophylaxis group suffered from chronic lung disease, defined as a need for supplemental oxygen with radiographic changes at 38 weeks post-conceptional age, compared with infants treated with rescue therapy. ${ }^{209}$ The infants who received prophylaxis had significantly lower mental and psychomotor Bayley scores at 12 months of age than infants who received rescue therapy. ${ }^{209}$ Thus, there is no advantage to the prophylactic administration of natural human surfactant.
Table 7 Meta-analysis of studies of prophylaxis compared with rescue with surfactant therapy

\begin{tabular}{llrr}
\hline & Control & Prophylaxis & \multicolumn{1}{c}{ Rescue } \\
\hline Incidence of IVH & $35.2(9.6)$ & $35.6(6.7)$ & $32.9(6.4)$ \\
Pneumothorax & 22.8 & $7.8(3.7)$ & $7.5(2.1)$ \\
BPD & $25.5(7)$ & $24.6(6.8)$ & $16.3(5.5)$ \\
Survival & 72.9 & $82.6(2.4)$ & $82.5(1.6)$ \\
Survival without BPD & 51.9 & $61.9(4.5)$ & $64(8.6)$
\end{tabular}

$\mathrm{IVH}=$ intraventricular haemorrhage; $\mathrm{BPD}=$ bronchopulmonary dysplasia.

Modified natural CLSE was used in a multicentre randomised trial comparing prophylactic administration with rescue therapy in infants of $<30$ weeks gestation. ${ }^{210}$ One minute Apgar scores were significantly lower in the group receiving prophylactic therapy. There was a significant decrease in the incidence of pneumothorax and a significant increase in survival in the infants receiving prophylaxis which was apparent only in infants at 26 weeks gestation. There were no differences in the incidence of chronic lung disease in either group, nor in the incidences of other acute problems such as IVH, PDA, necrotising enterocolitis, and retinopathy of prematurity. One major problem with this study is that the infants who received rescue therapy appeared to have had more severe disease which makes interpretation of the benefits of prophylaxis very difficult. Another randomised trial comparing prophylaxis with rescue therapy with CLSE found no differences in the incidence of air leak, BPD, or survival. ${ }^{211}$ Although there were significantly more infants in the prophylactic group who needed oxygen at 28 days gestation than in the rescue group, there were no significant differences in the number of infants requiring oxygen at 36 weeks post-conception, thus suggesting that there was no difference in the incidence of chronic lung disease between the two groups. Apgar scores at one minute were significantly depressed in the group receiving prophylaxis. The authors concluded that there "appears to be no clinical justification for routinely using a prophylactic approach ... in this population of neonates". ${ }^{211}$

Infants of 29-32 weeks gestation receiving prophylactic administration of CLSE had significantly fewer treatment failures as defined by the need for additional dosages and also had lower oxygen requirements than infants receiving rescue therapy. ${ }^{212}$ Infants at 30 weeks gestation in the prophylaxis group had a lower mortality rate and decreased need for supplemental oxygen at 28 days. There were no differences in acute complications such as air leaks, retinopathy of prematurity, and intraventricular haemorrhage. Infants receiving prophylactic therapy had significantly lower Apgar scores at one minute and there were significantly more administration errors in this group which included deposition of surfactant into the pharynx.

As shown in table 7 and fig 3, a meta-analysis comparing rescue therapy with prophylaxis shows that there is no advantage of prophylaxis in terms of the occurrence of IVH, survival, and survival without BPD. In fact, the relative risk of BPD is lowered in those receiving rescue 


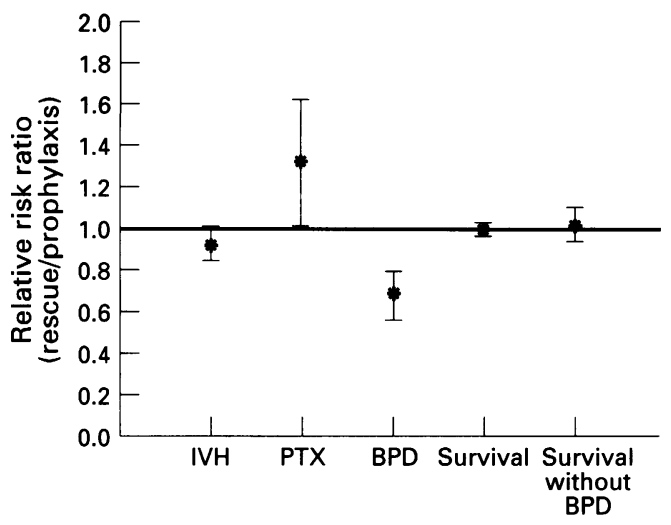

Figure 3 Meta-analysis of prophylaxis versus rescue trials using modified natural surfactant. Data represent the mean $\pm 95 \%$ confidence intervals for relative risk ratios for intraventricular haemorrhage (IVH), pneumothorax (PTX), bronchopulmonary dysplasia (BPD), survival, and survival without BPD. Confidence intervals which do not include the risk ratio of 1 indicate significant reductions $(<1)$ or increases $(>1)$ in the chances for a particular outcome variable.

therapy compared with those who received prophylaxis. There appear to be no differences in the duration of hospital stay between infants receiving prophylactic therapy and those given rescue therapy. As mentioned above, infants receiving prophylactic therapy have lower Apgar scores at one minute ${ }^{210-212}$ and one study showed lower Apgar scores at both one and five minutes. ${ }^{170}$ This raises the spectre of impacting adversely on long term outcome in infants receiving surfactant therapy prophylactically, especially before their stabilisation in the delivery room.

Given the lack of significant improvement in long term outcome in infants receiving prophylactic therapy, the significant disadvantages of delaying stabilisation in the delivery room, and the administration of surfactant to infants who might not have developed respiratory distress, it appears that prophylaxis offers no advantage over rescue therapy, especially in infants of $>26$ weeks gestational age. Treatment of infants with established HMD as early as possible appears to be prudent, however, as it lessens mortality, reduces short term complications such as air leaks, and improves survival without chronic lung disease.

SRT is now considered a standard of care for infants suffering from HMD. Administration of SRT must be performed by qualified neonatologists in level III neonatal intensive care units with all of the ancillary services, monitoring capabilities, and expertise in the management of neonates on mechanical ventilatory support. Indeed, the American Academy of Pediatrics has emphasised that SRT, which is now part of the armamentarium of therapeutic interventions in premature infants, should be administered only by neonatal specialists working in level III intensive care nurseries. ${ }^{213}$

Future research will help to answer may important unresolved questions. What is the optimal dose of surfactant? What is the optimal preparation? Is there a gestational age below which prophylaxis is clearly beneficial? What are the effects of surfactant therapy on endo- genous pulmonary surfactant production and metabolism? What other respiratory disorder will benefit from such therapy? How is cerebral metabolism and function affected by surfactant therapy?

The intense study of SRT in animals and in humans has become a paradigm for the blending of basic science and clinical science which has advanced the state of medical practice and impacted favourably on the survival and quality of life of our most tiny patients.

1 Avery ME, Mead RJ. Surface properties in relation to atelectasis and hyaline membrane disease. Am $\mathcal{F}$ Dis Child 1959;97:517-23.

2 Rooney SA. The surfactant system and lung phospholipid biochemistry. Am Rev Respir Dis 1985;131:439-60.

3 Jacobs HC, Berry DD, Duane G, Ikegami M, Jobe AH, Jones S. Normalization of arterial blood gases after treatment of surfactant-deficient lambs with Tween $20 . \mathrm{Am}$ Rev Respir Dis 1985;132:1313-8.

4 Gladstone IM, Ray AD, Salafia CM, Perez-Fontan J, Mercurio MR, Jacobs HC. Effect of artificial surfactant on pulmonary function in preterm and fullterm lambs. $\mathcal{F}$ Appl Physiol 1990;69:465-72.

5 Stark AR, Frantz ID. Respiratory distress syndrome. Pediatr Clin North Am 1986;33:533-44.

6 Wegman MA. Annual summary of vital statistics. Pediatrics 1992;90:835-45.

7 Kresch MJ, Gross I. The biochemistry of fetal lung development. Clin Perinatol 1987;14:481-507.

8 Rooney SA. Lung surfactant. Environ Health Perspect 1984; 55:205-26.

9 Hawgood S, Shiffer K. Structures and properties of the surfactant-associated proteins. Am Rev Physiol 1991;53: 375-94.

10 Weaver TE, Whitsett JA. Function and regulation of expression of pulmonary surfactant-associated proteins. Biochem f 1991;273:249-64.

11 Possmayer F. A proposed nomenclature for pulmonary surfactant-associated proteins. Am Rev Respir Dis 1988; 138:990-8.

12 Phelps DS, Floros J. Localization of surfactant protein synthesis in human lung by in situ hybridization. Am Rev Respir Dis 1988;137:939-42.

13 Auten RL, Watkins RH, Shapiro DL, Horowitz S. Surfactant A protein (SP-A) is synthesised in airway cells. Am $\mathcal{F}$ Respir Cell Mol Biol 1990;3:491-6.

14 Whitsett JA, Ross G, Weaver T, Rice W, Dion C, Hull W. Glycosylation and secretion of surfactant-associated glycoprotein A. F Biol Chem 1985;260:15273-9.

15 Whitesett JA, Weaver T, Hull W, Ross G, Dion C. Synthesis of surfactant-associated glycoprotein A by rat type II epithelial cells. Primary translation products and posttranslational modification. Biochim Biophys Acta 1985; 828:162-71.

16 Weaver TE, Ross G, Daugherty C, Whitsett JA. Synthesis of surfactant-associated protein, 35000 daltons, in fetal lung. $\mathcal{F}$ Biol Chem 1986;61:694-700.

17 Floros J, Phelps DS, Taeusch HW. Biosynthesis and in vitro translation of the major surfactant-associate protein from human lung. $₹$ Biol Chem 1985;260:495-500.

18 Floros J, Steinbrink R, Jacobs K, Phelps D, Kriz R, Recny $\mathrm{M}$, et al. Isolation and characterization of cDNA clones for the $35-\mathrm{kDa}$ pulmonary surfactant-associated protein. for the 35-kDa pulmonary surfact

19 Spissinger T, Schäfer KP, Voss T. Assembly of the surfactant protein SP-A. Deletions in the globular domain interfere with the correct folding of the molecule. Eur $\mathcal{F}$ Biochem 1991;199:65-71.

20 Haagsman HP, van Golde, LMG. Synthesis and assembly of lung surfactant. Annu Rev Physiol 1991;53:441-64.

21 Voss T, Eistetter H, Schäfer KP, Engel J. Macromolecular organization of natural and recombinant lung surfactant protein SP-28-36. F Mol Biol 1988;201:219-27.

22 Voss T, Melchers K. Scheirle G, Schäfer KP. Structural comparison of recombinant pulmonary surfactant protein SP-A derived from two human coding sequences: implications for the chain composition of natural human plications for the chain composition of natural

23 Wright JR, Wager RE, Hawgood S, Dobbs L, Clements JA. Surfactant apoprotein Mr-26000-36000 enhances uptake of liposomes by type II cells. $\mathcal{F}$ Biol Chem 1987, 262:2888-94.

24 Kuroki Y, Akino T. Roles of collagenous domain and oligosaccharide moiety of pulmonary surfactant protein $\mathrm{A}$ in interactions with phospholipids. Biochem Int 1991; 24:225-34.

25 Rice WR, Sarin VK, Fox JL, Baatz J, Wert S, Whitsett JA. Surfactant peptides stimulate uptake of phosphatidylcholine by isolated cells. Biochim Biophys Acta 1989;1006:237-45.

26 Kresch MJ, Cipriani LA, Lu H, Christian C. Developmental regulation of reuptake of phosphatidylcholine by type II alveo

Biophys Acta 1994;1210.167-73. Y Albino T Surfactan protein D co-interacts the inhibitory effect of surfactant 
protein $\mathrm{A}$ on phospholipid secretion by alveolar type II cells. Biochem f 1991;279:115-9.

28 Dobbs LG, Wright JR, Hawgood S, Gonzalez R, Venstrom $K$, Nellenbogen J. Pulmonary surfactant and its components inhibit secretion of phosphatidylcholine from
cultured rat alveolar type II cells. Proc Natl Acad Sci USA 1987;84:1010-4

29 Rice WR, Ross GF, Singleton FM, Dingle S, Whitsett JA. Surfactant-associated protein inhibits phospholipid secretion from type II cells. $\mathcal{F}$ Appl Physiol 1987;63:692-8.

30 Kuroki Y, Mason RJ, Voelker DR. Pulmonary surfactant apoprotein A structure and modulation of surfactant secretion by rat alveolar type II cells. $\mathcal{f}$ Biol Chem 1988 263:3388-94.

31 Kuroki Y, Mason RJ, Voekler DR. Chemical modification of surfactant protein A alters high affinity binding to rat alveolar type II cells and regulation of phospholipid secretion. F Biol Chem 1988;263:17596-602.

32 Williams MC, Hawgood S, Hamilton RL. Changes in lipid structure produced by surfactant proteins SP-A, SP-B and SP-C. Am $\mathcal{F}$ Respir Cell Mol Biol 1991;5:41-50.

33 Tenner AJ, Robinson SL, Borchelt J, Wright JR. Human pulmonary surfactant protein A, a protein structurally homologous to $C_{1} q_{1}$ can enhance FcR-and CRI-mediated phagocytosis. 7 Biol Chem 1989;264:13923-8.

34 Kremler SG, Phelps DS. Modulation of tumor necrosis factor production by surfactant protein A. Am Rev Respir Dis 1993;147:A228.

35 Whitsett JA, Hull Wm, Ohning B, Ross G, Weaver TE. Immunologic identification of a ulmonary surfactantassociated protein of molecular weight 6000 daltons. Pediatr Res 1986;20:744-9.

36 Whitsett JA, Ohning BL, Ross G, Merth J, Weaver T, Holm BA, et al. Hydrophobic surfactant-associated protein in whole lung surfactant and its importance for biophysical activity in lung surfactant extracts used for replacement therapy. Pediatr Res 1986;20:460-7.

37 Phelps DS, Smith LM, Taeusch HW. Characterization and partial amino acid sequence of a low molecular weight surfactant protein. Am Rev Respir Dis 1987;135:1112-7.

38 Liley HG, White RT, Warr RG, Benson BJ, Hawgood S, Ballard PL. Regulation of mRNAs for the hydrophobic Surfactant proteins in human lung. $\mathcal{F}$ Univ Invest 1989; 83:1191-7.

39 Jacobs KA, Phelps DS, Steinbrink R, Fisch J, Kriz R, Mitsock L, et al. Isolation of a cDNA clone encoding a high molecular weight precursor to a $6 \mathrm{kDa}$ pulmonary surfactant-associated protein. F Biol Chem 1987;262: surfactant-as

40 Cochrane CG, Revak SD. Pulmonary surfactant protein B: structure-function relationships Science 1991;254:566-8.

41 Longo ML, Bisagno AM, Zasadzinski JAN, Bruni R, Waring AJ. A function of lung surfactant protein SP-B. Science 1993;261:453-6.

42 Glasser SW, Korfhagen TR, Weaver TE, Clark JC, PilotMatins T, Menth J, et al. cDNA deduced polypeptide structure and chromosomal assignment of human pulmonary surfactant proteolipid, SPL. $₹$ Biol Chem 1988; 263:9-12.

43 Beers MF, Wali Avid, Eckenhoff MF, Feinstein SI, Fisher $\mathrm{JH}$, Fisher $\mathrm{AB}$. An antibody with specificity for surfactant protein $C$ precursors: identification of Pro-SP-C in rat lung. Am $\mathcal{f}$ Respir Cell Mol Biol 1992;7:368-78.

44 Persson A, Rust K, Chang D, Moxley M, Longmore W, Crouch E. CP4: a pneumocyte-derived collagenous surfactant-associated protein. Evidence for heterogeneity of collagenous surfactant proteins. Biochemistry 1988;27: 8576-84.

45 Persson A, Chang D, Rust U, Marley M, Longmore W, Crouch E. Purification and biochemical characterization of CPU (SP-D), a collagenous surfactant-associated protein. Biochemistry 1989;28:6361-7.

46 Persson A, Chang D, Crouch E. Surfactant protein D is a divalent cation-dependent carbohydrate-binding protein. F Biol Chem 1990;265:5755-60.

47 Crouch E, Rust K, Marienchek W, Parghi D, Chang D, Persson A. Developmental expression of pulmonary surfactant protein D (SP-D). Am f Respir Cell Mol Biol 1991;5:13-18.

48 Mason RJ, Dobbs LG, Greenleaf RD, Williams MC. Alveolar type II cells. Fed Proc 1977;36:2697-702.

49 Ballard PL, Ertsey R, Gonzales LK, Liley HG, Williams $\mathrm{MC}$. Isolation and characterization of differentiated alveolar type II cells from fetal human lung. Biochim Biophys Acta 1986;883:335-44.

50 Kresch MJ, Dynia DW, Gross I. Culture of differentiated and undifferentiated type II cells from fetal rat lung. Biochim Biophys Acta 1987;930:19-32.

51 Robinson PC, Voelker DR, Maison RJ. Isolation and culture of human alveolar type II epithelial cells. Characterization of their phospholipid secretion. Am Rev Respir Dis 1984;130:1156-60.

52 Sano K, Voekler DR, Mason RJ. Involvement of Protein Kinase $\mathrm{C}$ in Pulmonary Surfactant secretion from alveolar type II cells. F Biol Chem 1985;260:12725-9.

53 Gilfillan AM, Rooney SA. Arachidonic acid metabolites stimulate phosphatidylcholine secretion in primary cultures of type II pneumocytes. Biochim Biophys Acta 1985; 833:336-41.

54 Rooney SA, Gobran LI. Adenosine and leukotrienes have regulatory role in lung surfactant secretion in the newborn rabbit. Biochim Biophys Acta 1988;960:98-106.

55 Gilfillan AM, Rooney SA. Purinoceptor agonists stimulate phosphatidylcholine secretion in primary cultures of adult rat type II pneumocytes. Biochim Biophys Acta 1987;917: $18-23$

56 Wright JR, Clements JA. Metabolism and turnover of lung surfactant. Am Rev Respir Dis 1987;135:426-44.

57 Wright JR. Clearance and recycling of pulmonary surfactant. Am f Physiol (Lung Cell Mol Physiol) 1990;259: L1-12.

58 Chander A, Claypool WD, Strauss JF, Fisher AB. Uptake of liposomal phoshatidylcholine by granular pneumocytes in primary culture. Am $\mathcal{F}$ Physiol 1983;245:C 397-404.

59 Wright JR, Wager RE, Hamilton RL, Huang M, Clements JA. Update of lung surfactant subfractions into lamellar bodies of adult rabbit lungs. $\mathcal{f}$ Appl Physiol 1986;60: 817-25.

60 Chander A, Reicherter J, Fisher AB. Degradation of dipalmitoyl phosphatidylcholine by isolated rat granular pneumocytes and reutilization for surfactant synthesis. $\mathcal{f}$ plin Invest 1987;79:1133-8.

61 Fisher AB, Chander A, Reicherter J. Uptake and degradation of natural surfactant by isolated rat granular pneumocytes. Am f Physiol 1987;253:C792-6.

62 Young SL, Wright JR, Clements JA. Cellular uptake and processing of surfactant lipids and apoprotein SP-A by rat lung. $\mathcal{F}$ Appl Physiol 1989;66:1336-42.

63 Jobe A, Ikegami M. Surfactant for the treatment of respiratory distress syndrome. Am Rev Respir Dis 1987;136: 1256-75.

64 Shapiro DL, Notter RH, eds Surfactant replacement therapy. New York: Alan R Liss Inc, 1989.

65 Morley CJ, Bangham AD, Johnson P, Thorburn GD, Jenkin G. Physical and physiological properties of dry lung surfactant. Nature 1978;271:162-3.

66 Turcotte JG, Sacco AM, Steim JM, Tabak SA, Notter RH. Chemical synthesis and surface properties of an analog of the pulmonary surfactant dipalmitoyl phosphatidylcholine. Biochim Biophys Acta 1977;488:235-48.

67 Revak SD, Merrit TA, Hallman M, Cochrane CG. Reconstitution of surfactant activity using purified human apoprotein and phospholipids measured in vitro and in vivo. Am Rev Respir Dis 1986;134:1258-65.

68 Holm BA, Notter RH. Effects of hemoglobin and cell membrane lipids on pulmonary surfactant activity. $\mathcal{f} \mathrm{Appl}$ Physiol 1987;63:1434-42.

69 Notter RH, Shapiro DL, Ohning B Whitsett JA. Biophysical activity of synthetic phospholipids combined with purified lung surfactant 6000 dalton apoprotein. Chem Phys Lipids 1987;44:1-17.

70 Chung J, Yu SH, Whitsett JA, Harding PGR, Possmayer F. Effect of surfactant-associated protein-A (SP-A) on the activity of lipid extract surfactant. Biochim Biophys the activity of lipid extract

71 Schurch S, Bachofen H, Goerke J, Possmayer F. A captive bubble method reproduces the in situ behavior of lung surfactant monolayers. F Appl Physiol 1989;67:2389-96.

72 Venkitaraman AR, Hall SB, Whitsett JA, Notter RH. Enhancement of biophysical activity of lung surfactant extracts and phospholipid-apoprotein mixtures by surfactant protein A. Chem Phys Lipids 1990;56:185-94.

73 Holm BA, Keicher L, Liu M, Sololowski J, Enhorning G. Inhibition of pulmonary surfactant function by phospholipids. F Appl Physiol 1991;71:317-21.

74 Turcotte JG, Lin WH, Pivarnik PE, Sacco AM, Shirali SS, Bermel MM, et al. Chemical synthesis and surface activity of lung surfactant phospholipid analogs. II. Racemic N-substituted diether phosphonolipids. Biochim Biophys Acta 1991;1084:1-12.

75 Turcotte JG, Lin WH, Motola NC, Pivarnik PE, Bhongle NN, Heyman HR, et al. Chemical synthesis and surface activity of lung surfactant phospholipid analogs. III. Chiral N-substituted ether-amide phosphonolipids. Chem Phys Lipids 1991;58:81-95.

76 Enhorning G, Shumel B, Keicher L, Sokolowski J, Holm BA. Phospholipases introduced into the hypophase affect the surfactant film outlining a bubble. $\mathscr{f}$ Appl Physiol 1992;73:941-5.

77 Schurch S, Possmayer F, Cheng S, Cockshutt AM. Pulmonary SP-A enhances adsorption and appears to induce surface sorting of lipid extract surfactant. Am 7 Physiol (Lung Cell Mol Physiol 7) 1992;263:L210-18

78 Lu RZ, Turcotte JG, Lin WH, Steim JM, Notter RH. Differential scanning calorimetry of phosphonolipid analogs of lung surfactant glycerophospholipids. F Colloid Interface Sci 1992;154:24-34.

79 Obladen M, Popp D, Scholl C, Schwarz H, Jahnig F. Studies on lung surfactant replacement in respiratory distress syndrome rapid film formation from binary mixed distress syndrome rapid film formation from binary
liposomes. Biochim Biophys Acta 1983;735:215-24.

80 McLean LR, Krstenansky JL, Jackson RL, Hagman KA Olsen KF, Lewis JE. Mixtures of synthetic peptides and dipalmitoylphosphatidylcholine as lung surfactants. $A$ f Physiol (Lung Cell Mol Physiol 6) 1992;262:L 292-300.

81 McLean LR, Lewis JE, Hagaman KA, Owen TJ, Jackson RL. Amphipathic alpha-helical peptides based on surfactant apoprotein SP-A. Biochim Biophys Acta 1993; 1166:31-8.

82 Lachmann B. Animal studies of surfactant replacement therapy. Dev Pharmacol Ther 1989;13:164-72.

83 Bermel MS, McBride JT, Notter RH. Lavaged excised rat lungs as a model of surfactant deficiency. Lung 1984;162 lungs as a

84 Ikegami M, Silverman J, Adams FH. Restoration of lung pressure-volume characteristics with various phospholipids. Pediatr Res 1979;13:777-80.

85 McLean LR, Lewis JE, Krstenansky JL, Hagaman KA Cope AS, Olsen KF, et al. An amphipathic alpha-helical 
decapeptide in phosphatidylcholine is an effective synthetic lung surfactant. Am Rev Respir Dis 1993;147:462-5. 86 Bruni R, Hernandez-Juviel JM, Tanoviceanu R, David-Cu $\mathrm{R}$, Waring AJ, Walther FJ. Effects of synthetic surfactant SP-B, SP-C peptides on pressure/volume curves in a rat lung model of surfactant deficiency. Pediatr Res 1994;35: $327 \mathrm{~A}$.

87 Lachmann B, Robertson B, Vogel J. In vivo lung lavage as an experimental model of the respiratory distress syndrome. Acta Anaesth Scand 1980;24:231-6.

88 Berggren P, Lachman B, Curstedt T, Grossman G, Robertson B. Gas exchange and lung morphology after surfactant replacement in experimental adult respiratory
distress syndrome induced by repeated lung lavage. Acta distress syndrome induced by 1 .
Anaesth Scand 1986;30:321-8.

89 Kobayashi T, Kataoka H, Ueda T, Murakami S, Takada Y, Kokubo M. Effects of surfactant supplement and endexpiratory pressure in lung-lavaged rabbits. $\mathcal{F}$ Appl Physiol: Respir Environ Exerc Physiol 1984;57:995-1001.

90 Oetomo SB, Reijngoud DJ, Ennema JJ, Okken A, Wildevuur CRH. Surfactant replacement therapy in surfactant-deficient rabbits: early effects on lung function and biochemical aspects. Lung 1988;166:65-73.

91 Niblett DJ, Sandhar BK, Dunhill MS, Sykes MK. Comparison of the effects of high frequency oscillation and controlled mechanical ventilation on hyaline membrane formation in a rabbit model of the neonatal respiratory distress syndrome. $\mathrm{Br} \mathcal{F}$ Anaesth 1989;62:62-36.

92 Sandhar BK, Niblett DJ, Argiras EP, Dunnill MS, Sykes MK. Effects of positive end-expiratory pressure on hyaline membrane formation in a rabbit model of the neonatal respiratory distress syndrome. Intensive Care Med 1988; 14:538-46.

93 Davis JM, Russ GA, Metlay L, Dickerson B, Greenspan BS. Short-term distribution kinetics of intratracheally administered exogenous lung surfactant. Pediatr Res 1992; 31:445-50.

94 Lachmann B, Grossman G, Nilsson R, Robertson B. Effect of supplementary surfactant on in vivo lung mechanics in the premature rabbit neonate. Eur $\mathcal{F}$ Pediatr 1981;136: 173-9.

95 Nilsson R, Grossmam G, Berggren P, Robertson B. Surfactant treatment in experimental hyaline membrane disease. Eur Respir Dis 1981;62:441-9.

96 Nilsson $R$. The artificially ventilated preterm rabbit neonate as experimental model of hyaline membrane disease. Acta Anaesth Scand 1982;26:89-103.

97 Robertson B, Curtstedt T, Grossmann G, Kobayashi T, Kokubo M, Suzuki Y. Prolonged ventilation of the premature newborn rabbit after treatment with natural or apoprotein-based artificial surfactant. Eur $\mathcal{F}$ Pediatr 1988; 147:168-73.

98 Noack G, Curstedt T, Grossmann G, Nilsson R, Robertson B. Passive expiratory flow-volume recordings in immature newborn rabbits. Effect of surfactant replacement on the time constant of the respiratory system. Respiration 1990; 57:1-5.

99 Sun B, Kobayashi T, Curtstedt T, Grossmann G, Robertson B. Application of a new ventilator-multiplethysmograph system for testing efficacy of surfactant replacement in newborn rabbits. Eur Respir $\mathcal{F} 1991 ; 4$ 364-70.

100 Schneider HA, Hallman M, Benirschke K, Gluck L. Human surfactant: a therapeutic trial in premature rabbits. $\mathcal{F}$ Pediatr 1982;100:619-22.

101 Rider ED, Ikegami M, Whitsett JA, Hull W, Absolom D, Jobe AH. Treatment responses to surfactants containing natural surfactant proteins in preterm rabbits. Am Rev nespir Dis 1993;147:669-76.

102 Adams FH, Towers B, Osher AB, Ikegami M, Fujiwara $T$, Nozaki $M$. Effects of tracheal instillation of natural surfactant in premature lambs. I. Clinical and autopsy findings. Pediatr Res 1978;12:841-8.

103 Kolobow T, Solca M, Presenti A, Buckhold D, Pierce D. The prevention of hyaline membrane disease (HMD) in the preterm fetal lamb through the static inflation of the lungs: the conditioning of the fetal lungs. Trans $\mathrm{Am}$ Soc Artif Intern Organs 1980;26:567-72.

104 Ikegami M, Jobe A, Glatz T. Surface activity following natural surfactant treatment in premature lambs. $\mathcal{F}$ Appl Physiol: Respir Environ Exerc Physiol 1981;51:306-12.

105 Ikegami M, Jobe A, Jacobs H, Jones SJ. Sequential treatments of premature lambs with an artificial surfactant and natural surfactant. Clin Invest 1981;68:491-6.

106 Clyman RI, Jobe A, Heymann M, Ikegami M, Roman C Payne $\mathrm{B}$, et al. Increased shunt through the patent ductus arteriosus after surfactant replacement therapy. $\mathcal{F}$ Pediat 1982;100:101-7.

107 Solca M, Kolobow T, Huang H, Pesenti A, Buckhold D Pierce JE. Management of the antenatal preterm feta lung in the prevention of respiratory distress syndrome in lambs. Biol Neonate 1983;44:93-101.

108 Jobe A, Ikegami M, Glatz T, Yoshida Y, Diakomanolis E, Padbury J. Saturated phosphatidylcholine secretion and the effect of natural surfactant on premature end term the effect of natural surfactant on premature end term

109 Egan EA, Notter RH, Kwong MS, Shapiro DL. Natural and artificial lung surfactant replacement therapy in premature lambs. $\mathcal{J}$

110 Notter RH, Egan EA, Kwong MS, Holm BA, Shapiro DL Lung surfactant replacement in premature lambs with extracted lipids from bovine lung lavage: effects of dose, dispersion technique, and gestational age. Pediatr Res 1985;19:569-77.
111 Cummimgs JJ, Holm BA, Hudak ML, Hudak BB, Ferguson WH, Egan EA. A controlled clinical comparison of four different surfactant preparations in surfactantdeficient preterm lambs. Am Rev Respir Dis 1992;145: 999-1004.

112 Escobedo MB, Hilliard JL, Smith F, Meredith K, Walsh W, Johnson $\mathrm{D}$, et al. A baboon model of bronchopulmonary dysplasia. I. Clinical features. Exp Mol Pathol 1982;37: 323-34.

113 Coalson JJ, Kuehl TJ, Escobedo MB, Hilliard JL, Smith F, Meredith K, et al. A baboon model of bronchopulmonary dysplasia. II. Pathologic features. Exp Mol Pathol 1982; 37:335-50.

114 Maeta H, Raju TNK, Vidyasagar D, Bhat R, Esterly J, Matsuda $\mathrm{H}$, et al. Effect of exogenous surfactant on the development of bronchopulmonary dysplasia in a baboon hyaline membrane disease model. Crit Care Med 1990; 18:403-9.

115 Maeta H, Vidyasagar D, Raju T, Bhat R, Matsuda $H$. Response to bovine surfactant (surfactant TA) in two different HMD models (lambs and baboons). Eur $\mathcal{f}$ different HMD models

116 Maeta H, Vidasagar D, Raju TNK, Bhat R, Matsuda H. Early and late surfactant treatments in baboon model of hyaline membrane disease. Pediatrics 1988;81:277-83.

117 Shimada S, Raju TNK, Vidyasagar D, Maeta H, Bhat R. Chest radiographic course after exogenous surfactant therapy in baboons with respiratory distress syndrome. Crit Care Med 1990;18:969-73.

118 Jobe A, Ikegami M, Glatz T, Yoshida Y, Diakomanolis E, Padbury J. Duration and characteristics of treatment of premature lambs with natural surfactant. $\mathcal{f}$ Clin Invest premature lambs

119 Curstedt T, Jornvall H, Robertson B, Bergman T, Berrgren $\mathrm{P}$. Two hydrophobic low-molecular-mass protein fractions of pulmonary surfactant: characterization and biophysical activity. Eur f Biochem 1987;168:255-62.

120 Robertson B, Berry D, Curstedt T, Grossman G, Ikegami $\mathrm{M}$, Jacobs $\mathrm{H}$, et al. Leakage of protein in the premature rabbit lung: effect of surfactant replacement. Respir Physiol $1985 ; 61: 265-76$

121 Morley C, Robertson B, Lachmann B, Nilsson R, Bangham A, Grossmann G, et al. Artificial surfactant and natural surfactant. Arch Dis Child 1980;55:758-65.

122 Grossmann G, Larsson I, Nilsson R, Robertson B, Rydhag $L$, Stenius $P$. Lung expansion in premature newborn rabbits treated with emulsified synthetic surfactant: principles for experimental evaluation of synthetic substitutes for pulmonary surfactant. Respiration 1984;45:327-38.

123 Jacobs H, Jobe A, Ikegami M, Glatz T, Jones SJ, Barajas L. Premature lambs rescued from respiratory failure with natural surfactant: clinical and biophysical correlates. Pediatr Res 1982;16:424-9.

124 Ikegami M, Adams FH, Towers B, Osher AB. The quantity of natural surfactant necessary to prevent the respiratory distress syndrome in premature lambs. Pediatr Res 1980; 14:1082-5.

125 Walther FJ, Blanco CE, Houdijk M, Bevers EM. Single versus repetitive doses of natural surfactant as treatment of respiratory distress syndrome in premature lambs. Pediatr Res 1985;19:224-6.

126 Ikegami M, Jobe A, Jacobs H, Jones SJ. Sequential treatments of premature lambs with an artificial surfactant and natural surfactant. 7 Clin Invest 1981;68:491-6.

127 Ikegami M, Jobe A, Glatz T. Surface activity following natural surfactant treatment in premature lambs. $\mathcal{f} A p p l$ Physiol: Respir Environ Exerc Physiol 1981;51:306-12.

128 Adams FH, Towers B, Osher AB, Ikegami M, Fujiwara $T$, Nozaki $M$. Effects of tracheal instillation of natural surfactant in premature lambs. I. Clinical and autopsy findings. Pediatr Res 1978;12:841-8.

129 Jobe A, Ikegami M, Jacobs H, Jones S. Surfactant and pulmonary blood flow distributions following treatment of premature lambs with natural surfactant. $\mathcal{F}$ Clin Invest 1984;73:848-56.

130 Durand DJ, Clyman RI, Heymann MA, Clements JA, Mauray F, Kitterman J, et al. Effects of a protein-free, synthetic surfactant on survival and pulmonary function in preterm lambs. $\mathcal{F}$ Pediatr 1985;107:775-80.

131 Enhorning G, Robertson B, Milne E, Wagner R. Radiologic evaluation of the premature newborn rabbit after pharyngeal deposition of surfactant. Am $\mathcal{f}$ Obstet Gynecol 1975;121:475-80.

132 SuzukiY, Curstedt T, Grossmann G, Kobayashi T, Nilsson $\mathrm{R}$, Nohara $\mathrm{K}$, et al. The role of the low molecular weight ( $<15000$ daltons) apoproteins of pulmonary surfactant. (<ur $₹$ Respir Dis 1986;69:336-45.
Re

133 Ikegami M, Jobe AH, Tabor BL, Rider ED, Lewis JF. Lung albumin recovery in surfactant-treated preterm ventilated lambs. Am Rev Respir Dis 1992;145:1005-8.

134 Egan E, Notter R, Kwong M, Shapiro DL. Natural and artificial lung surfactant replacement in premature lambs. f Appl Physiol: Respir Environ Exerc Physiol 1983;55:87583.

135 Vilstrup C, Gommers D, Bos AH, Lachmann B, Werner $\mathrm{O}$, Larsson A. Natural surfactant instilled in premature lambs increases lung volume and improves ventilation homogeneity within five minutes. Pediatr Res 1992;32: 595-9.

136 Ikegami M, Ueda, Absolom D, Baxter C, Rider E, Jobe A. Changes in exogenous surfactant in ventilated preterm A. Changes in exogenous surfactant in ventilated pr

137 Ikegami M, Agata Y, Elkady T, Hallman M, Berry D, Jobe A. Comparison of four surfactants: in vitro surface 
properties and responses of preterm lambs to treatment at birth. Pediatrics 1987;79:38-46.

138 Nohara K, Berggren P, Curstedt T, Grossmann G, Nilsson $R$, Robertson B. Correlations between physical and physiological properties of various preparations of lung surfactant. Eur ₹ Respir Dis 1986;69:321-35.

139 Tanaka Y, Takei T, Masuda K. Lung surfactants. III. Correlations among activities in vitro, in situ and in vivo, and chemical composition. Chem Pharm Bull 1983;31: $4110-5$

140 Tanaka Y, Takei T, Kanazawa Y. Lung surfactant. II. Effects of fatty acids, triacylglycerols and protein on the activity of lung surfactant. Chem Pharm Bull 1983;31: 4100-9.

141 Tanaka Y, Takei T, Aiba T, Masuda K, Kiuchi A, Fujiwara T. Development of synthetic lung surfactants. $\mathscr{f}$ Lipid Res 1986;27:475-85.

142 Ikegami M, Silverman J, Adams FH. Restoration of lung pressure-volume characteristics with various phospholipids. Pediatr Res 1979;13:777-80.

143 Lin WH, Turcotte JG, Parkinson D, Thrall RS. Restoration of lung compliance with calf lung surfactant extract and a surfactant analog in an in situ model of surfactant deficiency in rats. Respiration 1995 (in press).

144 van't Veen A, So KL, Lachmann B. Surfactant replacement therapy in animal models of respiratory failure due to viral infection. In: Vaupel P, ed. Oxygen transport to tissue. New York: Plenum Press, 1994;15:83-94.

145 Eijking EP, van Daal GJ, Tenbrinck R, Sluiters JF, Hannappel E, Lachmann B. Improvement of pulmonary gas exchange after surfactant replacement in rats with pneumocystis carinii pneumonia. Adv Exp Med Biol 1992;316: 293-8

146 Eijking EP, van Daal GJ, Tenbrinck R, Luijendijk A, Sluiters JF, Hannappel, et al. Effect of surfactant replacement on Pneumocystis carinii pneumonia in rats. Intensive Care Med 1991;17:475-8.

147 Engstrom PC, Holm BA, Matalon S. Surfactant replacement attenuates the increase in alveolar permeability placement attenuates the increase in alveolar pen
in hyperoxia. $₹$ Appl Physiol 1989;67:688-93.

148 Ennema JJ, Kobayashi T, Robertson B, Curstedt T. Inactivation of exogenous surfactant in experimental respiratory failure induced by hyperoxia. Acta Anaesth Scand 1988;32:665-71.

149 Robertson B. Surfactant inactivation and surfactant replacement in experimental models of ARDS. Acta Anaesth Scand 1991;35(Suppl 95):22-8.

150 Lamm WJE, Albert RK. Surfactant replacement improves lung recoil in rabbit lungs after acid aspiration. Am Rev Respir Dis 1990;142:1279-83.

151 Berry D, Ikegami M, Jobe A. Respiratory distress and surfactant inhibition following vagotomy in rabbits. $\mathcal{F} \mathrm{Appl}$ Physiol 1986;61:1741-8.

152 Lachmann B, Armbruster S, Erdmann W. Oxygen uptake and surfactant replacement. Adv Exp Med Biol 1988;222: 511-7.

153 Robillard E, Alarie Y, Dagenais-Perusse P, et al. Microaerosol administration of synthetic dipalmitoyl lecithin in the respiratory distress syndrome: a preliminary report. Can Med Assoc $₹$ 1964;90:55-7.

154 Chu J, Clements JA, Cotton EK, et al. Neonatal pulmonary ischemia: clinical and physiologic studies. Pediatrics 1967 ; 40:709-82.

155 Milner AD, Vyas H, Hopkin IE. Effects of artificial surfactant on lung function and blood gases in idiopathic respiratory distress syndrome. Arch Dis Child 1983;58: 458-60.

156 Fujiwara T, Chida S, Watabe Y, Maeta H, Morita T, Abe T. Artificial surfactant therapy in hyaline-membran disease. Lancet 1980;i:55-9.

157 Raju TNK, Vidyasagar D, Bhat R, Sobel D, McCulloch $\mathrm{KM}$, Anderson $\mathrm{M}$, et al. Double-blind controlled trial of single-dose treatment with bovine surfactant in severe single-dose treatment with bovine surfactant in

158 Gitlin JD, Soll RR, Parad RR, Horbar JD, Feldman HA, Lucey JF, et al. Randomised controlled trial of exogenouse surfactant for the treatment of hyaline membrane disease. Pediatrics 1987;79:31-7.

159 Fujiwara T, Konishi M, Chida S, Okuyama K, et al. Surfactant replacement therapy with a single postventilatory dose of a reconstituted bovine surfactant in preterm neonates with respiratory distress syndrome: final analysis of a multicenter, double-blind randomised trial and comparison with similar trials. Pediatrics 1990;86: 753-64.

160 Dunn MS, Shannan AT, Possmeyer R. Single versus multiple-dose surfactant replacement therapy in neonates of 30 to 36 weeks gestation with respiratory distres syndrome. Pediatrics 1990;86:564-71.

161 Horbar JD, Soll RF, Sutherland JM, Kotagal U, et al. A European multicenter randomised controlled trial of single dose surfactant therapy for idiopathic respiratory distress syndrome. $N$ Engl 7 Med 1989;320:959-65.

162 Horbar JD, Soll RF, Schachinger H, Kewitz G, et al. A European multicenter randomised controlled trial of single dose surfactant therapy for idiopathic respiratory distress syndrome. Eur $\mathcal{F}$ Pediatr 1990;149:416-23.

163 Liechty EA, Donovan E, Purohit D, Gilhooly J, et al. Reduction of neonatal mortality after multiple doses of bovine surfactant in low birth weight neonates with respiratory distress syndromirth weight neonates with

164 Collaborative European Multicenter Study Group. Surfactant replacement therapy for severe neonatal respiratory distress syndrome: an international randomised clinical trial. Pediatrics 1988;82:683-91.
165 Halliday HL, McCord FB, McClure BG, McCreid M. Acute effects of instillation of surfactant in severe respiratory distress syndrome. Arch Dis Child 1989;64:13-16.

166 Robertson B. European multicenter trials of Curosurf for treatment of neonatal respiratory distress syndrome. Lung (Suppl) 1990;860-3.

167 Speer CP, Robertson B, Curstedt T, Halliday HL, et al. Randomised European multicenter trial of surfactant replacement therapy for severe neonatal respiratory distress syndrome: single vs. multiple doses of Curosurf. Pediatrics 1992;89:13-20.

168 Hallman M, Merritt TA, Jarvenpopa A-L, Boynton B, et al. Exogenous human surfactant for treatment of severe respiratory distress syndrome: a randomised prospective clinical trial. 7 Pediatr 1985;106:963-69.

169 Lang MJ, Hall RT, Reddy NS, Kurth CG, Merritt TA. A controlled trial of human surfactant replacement therapy for severe respiratory distress syndrome in very low birth weight infants. F Pediatr 1990;116:295-300.

170 Phibbs RH, Ballard RA, Clements JA, Heilbron DC, et al. Initial trial of Exosurf, a protein-free synthetic surfactant, for the prophylaxis and early treatment of hyaline-membrane disease. Pediatrics 1991;88:1-9.

171 Long W, Corbet A, Cotton R, Courtney S, et al. A controlled trial of synthetic surfactant in infants weighing $1250 \mathrm{~g}$ or more with respiratory distress syndrome. $N$ Engl f Med 1991;325:1696-703.

172 Long W, Thompson T, Sundell H. Schumacher R, et al. Effects of two reserve doses of a synthetic surfactant on mortality rate and survival without bronchopulmonary dysplasia in 700 to 1350 gram infants with respiratory distress syndrome. 7 Pediatr 1991;118:595-605.

173 Charon A, Taeusch HW, Fitzgibbon C, Smith GB, et al. Factors associated with surfactant treatment response in infants with severe respiratory distress syndrome. $\mathrm{Pe}$ diatrics $1989 ; 83: 348-54$.

174 Collaborative European Multicenter Study Group. Factors influencing the clinical response to surfactant replacement therapy in babies with severe respiratory distress syndrome. Eur $\mathcal{F}$ Pediatr 1991;150:433-9.

175 Speer CP, Harms K, Hertting E, Newmann, et al. Early versus late surfactant replacement therapy in severe respiratory distress syndrome. Lung (Suppl) 1990;?:870-6.

176 Zola EM, Gunkel JH, Chan RK, Lim MD, Knox I, et al. Comparison of three dosing procedures for administration of bovine surfactant to neonates with respiratory distress syndrome. F Pediatr 1993;122:453-9.

177 Merritt ATA, Hallman M, Holcomb K, Strayer D, et al. Human surfactant treatment of severe respiratory distress syndrome: pulmonary effluent indicators of lung insyndrome: pulmonary effluent indica

178 Arnon J, Grigg J, Silverman M. Pulmonary inflammatory cells in ventilated preterm infants: effect of surfactant treatment. Arch Dis Child 1993;69:44-8.

179 Chida S, Phelps DS, Soll RR, Taeusch HW. Surfactant proteins and anti-surfactant antibodies in sera from infants with respiratory distress syndrome with and without Surfactant treatment. Pediatrics 1991;88:84-9.

180 Whitsett JA, Hull WM, Luse S. Failure to detect surfactant protein-specific antibodies in sera of premature infants treated with Survanta, a modified bovine surfactant. $P e$ diatrics 1991;87:505-10.

181 Ware J, Taeusch HW, Soll RF, McCormick MC. Health and developmental outcomes of a surfactant controlled trial: follow up at 2 years. Pediatrics 1990;85:1103-7.

182 Maniscalco WM, Kendig JW, Shapiro DL. Surfactan replacement therapy: impact on hospital charges for premature infants with respiratory distress syndrome. $\mathrm{Pe}$ diatrics 1989;83:1-6.

183 Auten RL, Notter RH, Kendig JW, Davis JM, Shapiro DL. Surfactant treatment of fullterm newborns with respiratory failure. Pediatrics 1991;87:101-7.

184 Khammash H, Perlman M, Wojtulewicz J, Dunn M. Surfactant therapy in full-term neonates with severe respiratory failure. Pediatrics 1993;92:135-9.

185 Canadian Exosurf Pediatric Study Group. Effects of two rescue doses of Exosurf Pediatrics in 342 750-1249 gram infants. Pediatr Res 1990;27:200A.

186 Smyth J, Allen A, Sankaran K, MacMurray B, et al. Effects of two rescue doses of Exosurf Neonatal in 221 500-749 gram infants. Pediatr Res 1991;29:330A.

187 Cotton RB, Olsson $T$, Law AB, et al. The physiologic basis for surfactant effect on gas exchange in newborn premature infants treated for hyaline-membrane disease. premature infants treated

188 The OSIRIS Collaborative Group. Early versus delayed neonatal administration of a synthetic surfactant - the judgment of OSIRIS. Lancet 1992;340:1363-9.

189 Kaapa P, Kero P, Saraste M. Synthetic surfactant replacement therapy decreases estimated pulmonary artery pressure in respiratory distress syndrome. $A m \mathcal{F}$ Dis Child 1992;146:961-4.

190 Kaapa P, Seppanen M, Kero P, Saraste M. Pulmonary hemodynamics after synthetic surfactant replacement in neonatal respiratory distress syndrome. $\mathcal{F}$ Pediatr 1993; 123:115-9.

191 Abbasi J, Bhutani VK, Gerdes JS. Long-term pulmonary consequences of respiratory distress syndrome in preterm infants treated with exogenous surfactant. $\mathcal{F}$ Pediatr 1993 122:446-56.

192 Van de Bor M, Ma EJ, Walther FJ. Cerebral blood flow velocity after surfactant instillation in preterm infants. $\mathcal{F}$ Pediatr 1991;118:285-7.

193 Robin BK, Ramirez O, King M. Mucus rheology and transport in neonatal respiratory distress syndrome and 
the effect of surfactant therapy. Chest 1992;101:1080-5.

194 Horbar JD, Wright LL, Soll RF, Wright EC, et al. A multicenter randomised trial comparing two surfactants for the treatment of neonatal respiratory distress synfor the treatment of neonatal resp.

195 Enhorning G, Shennan A, Possmayer F, Dunn M, et al. Prevention of neonatal respiratory distress syndrome by tracheal instillation of surfactant: a randomised clinical trial. Pediatrics 1985;76:145-53.

196 Kwong MS, Egan EA, Notter RH, Shapiro DL. Doubleblind clinical trial of calf lung surfactant extract for the prevention of hyaline-membrane disease in extremely premature infants. Pediatrics $1985 ; 76: 585-92$.

197 Shapiro DL, Notter RH, Morin FC, Deluga KS, Golub LM, et al. Double-blind, randomised trial of a calf lung surfactant extract administered at birth to very premature infants for prevention of respiratory distress syndrome. infants for prevention of
Pediatrics 1985;76:593 9

198 Soll RF, Hoekstra RE, Fangman JJ, Corbet AJ, et al. Multicenter trial of single-dose modified bovine surfactant extract (Survanta) for prevention of respiratory distress syndrome. Pediatrics 1990;85:1092-102.

199 Hoekstra RE, Jackson JC, Myers TR, Frantz ID, et al. Improved neonatal survival following multiple doses of bovine surfactant in very premature neonates at risk for roviratory distress syndrome. Pediatrics 1991;88:10-18.

200 Merritt TA, Hallmen M, Bloom BT, Berry C, et al. Prophylactic treatment of very premature infants with human phylactic treatment of very premature infants
surfactant. $N$ Engl $₹$ Med 1986;315:785-90.

201 Gortner L, Bernsau U, Hellwege HH, Hieronimi G, Jorch G, Reiter HL. A multicenter randomised controlled clinical trial of bovine surfactant for prevention of respiratory distress syndrome. Lung (Suppl) 1990:864-9.

202 Hallman M, Merritt TA, Bry K, Kerry C. Association between neonatal care practices and efficacy of exogenous human surfactant: results of a bicenter randomised trial. Pediatrics 1993;91:552-60.

203 Bose C, Corbet A, Bose G, Garcia-Prats J, et al. Improved outcome at 28 days of age for very low birth weight infants teated with a single dose of a synthetic surfactant. $\mathcal{f}$ Pediatr 1990;117:947-53.
204 Corbet A, Bucciarelli R, Goldman S, Mammel M. Decreased mortality rate among small premature infants treated at birth with a single dose of synthetic surfactant: treated at birth with a single dose of synthetic surfactant:

205 Hellstrom-Westas L, Bell AH, Skor L, Greisan G, Svenningsen NW. Cerebroelectrical depression following surfactant treatment in preterm neonates. Pediatrics 1992; 89:643-7.

206 Morley CJ, Greenough A, Miller NG, Bangham AD, Pool $\mathrm{J}$, Wood S, et al. Randomised trial of artificial surfactant (ALEC) given at birth to babies from 23 to 34 weeks gestation. Early Human Development 1988;17:41-54.

207 Ten Centre Study Group. Ten centre trial of artificial surfactant (artificial lung expanding compound) in very premature babies. BMF 1987;294:991-6.

208 Merritt TA, Hallman M, Berry C, Pohjavuori M, et al. Randomised, placebo-controlled trial of human surfactant Randomised, placebo-controlled trial of human surfactant
given at birth versus rescue administration in very low given at birth versus rescue administration in very low
birth weight infants with lung immaturity. $\mathcal{F}$ Pediatr 1991 ; 118:581-94.

209 Vaucher YE, Harker L, Merritt TA, Hallman M, et al. Outcome at twelve months of adjusted age in very low birth weight infants with lung immaturity: a randomised, placebo-controlled trial of human surfactant. $\mathcal{F}$ Pediatr 1993;122:126-32.

210 Kendig JW, Notter RH, Cox C, Reubens LJ, et al. A comparison of surfactant as immediate prophylaxis and as rescue therapy in newborns of less than 30 weeks as rescue therapy in newborns of less than
gestation. $N$ Engl $f$ Med 1991;324:865-71.

211 Dunn MS, Shennan AT, Zayack D, Possmayer R. Bovine surfactant replacement therapy in neonates of less than 30 weeks gestation: a randomised controlled trial of prophylaxis veruss treatment. Pediatrics 1991;87:377-86.

212 Kattwinkel J, Bloom BT, Delmore P, Davis CL, et al. Prophylactic administration of calf lung surfactant extract is more effective than early treatment of respiratory distress syndrome in neonates of 29 through 32 weeks gestation. Pediatrics 1993;92:90-8.

213 American Academy of Pediatrics Committee on Fetus and Newborn. Surfactant replacement therapy for RDS. Pediatrics 1991;87:946-7. 